This item was submitted to Loughborough's Research Repository by the author.

Items in Figshare are protected by copyright, with all rights reserved, unless otherwise indicated.

\title{
Capabilities for advanced services: a multi-actor perspective
}

PLEASE CITE THE PUBLISHED VERSION

http://dx.doi.org/10.1016/j.indmarman.2016.04.015

\section{PUBLISHER}

(C) Elsevier

\section{VERSION}

AM (Accepted Manuscript)

\section{PUBLISHER STATEMENT}

This work is made available according to the conditions of the Creative Commons Attribution-NonCommercialNoDerivatives 4.0 International (CC BY-NC-ND 4.0) licence. Full details of this licence are available at: https://creativecommons.org/licenses/by-nc-nd/4.0/

\section{LICENCE}

CC BY-NC-ND 4.0

\section{REPOSITORY RECORD}

Story, Vicky, Chris Raddats, Jamie Burton, Judy Zolkiewski, and Tim Baines. 2019. "Capabilities for Advanced Services: A Multi-actor Perspective". figshare. https://hdl.handle.net/2134/22544. 
Final version accepted for Publication

CAPABILITIES FOR ADVANCED SERVICES:

\section{A MULTI-ACTOR PERSPECTIVE}

This is a pre-print (non-publisher's document). Please cite the published article:

Please cite this article as: Story, V.M., Raddats, C., Burton, J., Zolkiewski, J. and Baines, T., Capabilities for advanced services: A multi-actor perspective, Industrial Marketing Management, (2016), http://dx.doi.org/10.1016/j.indmarman.2016.04.015.

Vicky M. Story ${ }^{\mathrm{a} *}$; Chris Raddats ${ }^{\mathrm{b}}$, Jamie Burton ${ }^{\mathrm{c}}$, Judy Zolkiewski ${ }^{\mathrm{c}}$, Tim Baines ${ }^{\mathrm{d}}$

a School of Business and Economics, Loughborough University, Ashby Road, Loughborough, LE11 3TU, UK, v.m.story@lboro.ac.uk, Telephone number: +441509228301

${ }^{\mathrm{b}}$ University of Liverpool Management School, University of Liverpool, Chatham Street, Liverpool, L69 7ZH, UK. C.Raddats@liverpool.ac.uk

${ }^{\mathrm{c}}$ Manchester Business School, University of Manchester, Booth Street West, Manchester, M15 6PB, UK. Jamie.Burton@mbs.ac.uk; Judy.Zolkiewski@mbs.ac.uk

${ }^{\mathrm{d}}$ Aston Business School, Aston University, Aston Triangle, Birmingham, B4 7ET, UK.

T.Baines@aston.ac.uk

* Corresponding author 
Final version accepted for Publication

\begin{abstract}
Servitization involves manufacturers developing service offerings to grow revenue and profit. Advanced services, in particular, can facilitate a more service-focused organization and impact customers' business processes significantly. However, approaches to servitization are often discussed solely from the manufacturer's perspective; overlooking the role of other network actors. Adopting a multi-actor perspective, this study investigates manufacturer, intermediary and customer perspectives to identify complementary and competing capabilities within a manufacturer's downstream network, required for advanced services. Interviews were conducted with 24 senior executives in 19 UK-based manufacturers, intermediaries and customers across multiple sectors. The study identified six key business activities, within which advanced services capabilities were grouped. The unique and critical capabilities for advanced services for each actor were identified as follows: manufacturers; the need to balance product and service innovation, developing customer-focused through-life service methodologies and having distinct, yet synergistic product and service cultures; intermediaries, the coordination and integration of third party products/services; customers, co-creating innovation and having processes supporting service outsourcing. The study is unique in highlighting the distinct roles of different actors in the provision of advanced services and shows that they can only be developed and delivered by the combination of complex interconnected capabilities found within a network.
\end{abstract}

\title{
KEY WORDS
}

Servitization, Advanced Services, Capabilities, Complementary capabilities, Network actors 
Final version accepted for Publication

\section{RESEARCH HIGHLIGHTS:}

- We explore the capabilities required for advanced services from the perspectives of three actors; manufacturers, intermediaries and customers.

- Within six key business activities, competitive (manufacturer, intermediary) and complementary (customer) capabilities are identified, six of which are unique and critical for advanced services.

- For manufacturers, these unique and critical capabilities are: the need to balance product and service innovation, developing customer-focused through-life service methodologies and having distinct, yet synergistic product and service cultures.

- For intermediaries, a unique and critical capability is the coordination and integration of third party products/services.

- For customers, these capabilities are: co-creating innovation and having processes supporting service outsourcing.

- The study shows that advanced services are developed and delivered by multiple actors combining complex interconnected capabilities within a network. 
Final version accepted for Publication

\section{INTRODUCTION}

Servitization has been heralded as a means for manufacturers, facing significant challenges in their core product markets, to achieve competitive advantage and create improved customer value (Baines, Lightfoot, Benedettini \& Kay, 2009; Vandermerwe \& Rada, 1988). It involves manufacturers developing new services to go alongside their core product offerings or even to replace their product offerings. These new services are argued to deliver customer value (Baines et al., 2009; Guajardo, Cohen, Netessine \& Kim, 2011; Vandermerwe \& Rada, 1988) and generate sales revenue and profitability for firms (Fang, Palmatier \& Steenkamp, 2008). However, the shift in processes needed for effective servitization can be difficult and further research is required to understand the relevant business models for traditionally product-based organizations looking to servitize (Lightfoot \& Gebauer, 2011; Ostrom et al., 2010).

This need for understanding is further exacerbated because services developed by servitizing firms are complex and varied. Indeed, significant work has been done creating classifications for these services. Many of these classifications distinguish between whether the service is focused on the product (Services Supporting the Product [SSP]) or the customer and their activities (Services Supporting the Customer [SSC]) (Mathieu, 2001); and highlight a range of service types from ‘base services’ (e.g., spare parts), focused on supporting product provision, to ‘intermediate services' (e.g., maintenance, repair and overhaul [MRO]), focused on maintenance of the product condition; and 'advanced services' (e.g., availability contracting and risk and revenue sharing) (Baines \& Lightfoot, 2014). The latter involves bundling together products and services into complex offerings that are crucial to the customer's core business processes and have been defined as: "a capability delivered through product performance and often featuring; relationships over extended life-cycle, extended responsibilities and regular revenue payments” (Baines \& Lightfoot, 2014: 22). This inherent complexity requires manufacturers to develop customer relationship building and management capabilities in order to foster an intimate understanding of their customers' business activities and, thus, how their service offerings might support the customer's core activities (Mathieu, 2001). While SSPs tend to be fixed and relatively easily defined, (e.g., delivering replacement 
Final version accepted for Publication

parts), SSCs are by their nature more dynamic. Indeed, Mathieu (2001: 40) suggests that “the supplier's work concerning the [advanced] service offer never really ends”. Thus, advanced services cannot be easily classified and listed, but instead should be seen as complex, flexible, offerings; developed in order to rapidly respond to customers’ needs, by providing performance-based services that support these customers' dynamic and evolving activities. Given their complexity, advanced services, in particular, can have a major impact on both manufacturer and customer operations (Baines \& Lightfoot, 2013). However, work has only recently begun to explore the specific challenges of developing advanced services.

Extant research suggests that moving to service provision requires a substantial shift in development capabilities (Antioco, Moenaert, Lindgreen \& Wetzels, 2008). This research has begun to discuss the complexity of developing and managing resources and capabilities required for successful servitization. Paiola, Saccani, Perona \& Gebauer (2013) identify the potential internal, external or mixed development of capabilities for four types of services components (services supporting the pre-sales phase, the sales phase, the after-sales phase, and the reconfiguration of customer activities). In a quantitative study of 155 UK manufacturers, Raddats, Burton \& Ashman (2015) identify resource configurations enabling the delivery of services, highlighting the statistically significant contribution of developing 'leaders and services personnel' and 'services methods and tools' to success of services. However, despite Paiola et al.'s (2013) observation that capabilities can be developed outside of the organization, servitization capabilities are often discussed from a focal manufacturer’s perspective (e.g., Ulaga \& Reinartz 2011). The general presumption is that manufacturers assume responsibility for activities previously performed 'downstream' (Mathieu, 2001; Spring \& Araujo, 2013) in order to grow their revenue through developing the scope of their offerings. A significant problem with such an approach is that manufacturers' internal capabilities are often inadequate for successful servitization (Paiola et al., 2013). Thus, manufacturers may need to develop new service-oriented relational capabilities, in order to work with actors in their network (Baines \& Lightfoot, 2013; Gebauer, Paiola \& Saccani, 2013; Storbacka, 2011). This is particularly true for advanced services, compared with other less complex types of services (Brax \& Jonsson, 2009), as they are more likely to require an integrated network of actors, beyond just the focal manufacturer (Araujo, Dubois \& 
Final version accepted for Publication

Gadde, 2003; Kowalkowski, Kindström \& Witell, 2011), acting together to generate capabilities supporting the creation of such novel value offerings (Baines \& Lightfoot, 2013).

Research has explored whether firms should develop capabilities internally or externally (Paiola et al., 2013). For example, Davies (2004) offers the concepts of ‘system seller’ for firms that develop capabilities internally and 'system integrator' for firms that adopt an external approach. Work by Kowalkowski et al. (2011) extends this to include a hybrid or mixed approach, where some capabilities are developed internally and some externally. There is, however, limited empirical research addressing the specific servitization capabilities that may need to be developed by different network actors. Hence, this study aims to investigate the manufacturer, intermediary and customer perspectives of the capabilities necessary for successful servitization with regards to advanced services.

This research makes three key contributions. First, we explicate key capabilities for advanced services. While extant literature has uncovered numerous servitization capabilities, there are still calls for a deeper understanding of how to successfully servitize (Ulaga \& Reinartz, 2011); particularly in terms of the capabilities firms need to develop. Our specific focus on advanced services is in response to suggestions that critical resources and capabilities will differ for different types of services (Raddats et al., 2015; Ulaga \& Reinartz, 2011). Second, by looking beyond the focal manufacturer's perspective, and taking a multiactor perspective, we identify where these capabilities develop within a network and how network actors can support manufacturers' servitization efforts with regards to advanced services. While the literature, for the most part, suggests that servitizing manufacturers gain at the expense of other actors in the network (particularly intermediaries), given the complexity of advanced services, it is actually more likely that these services will be delivered by a network of business actors (Ng, Parry, Maull, \& McFarlane, 2011). This necessarily infers that other network actors may also need specific capabilities to support servitization efforts. However, currently there is limited research that examines the capabilities developed by network actors. Finally, we explore whether there is also a need for customers to build complementary capabilities (Spring \& Araujo, 2014) in order to support the successful delivery of advanced services. The role of 
Final version accepted for Publication

customers as co-creators of value (Vargo \& Lusch, 2008; 2011) has been considered, with some work specifically focusing on a servitization context (e.g. Bastl, Johnson, Lightfoot \& Evans, 2012). However, research has yet to examine the specific complementary capabilities that might be required by business-tobusiness (B2B) customers as part of the servitization process.

The paper is structured as follows. First, key literature is reviewed and research questions developed. The next section outlines the methodological approach adopted and details the data collected. This is followed by the findings and discussion, then conclusions and recommendations. Finally, limitations and further research avenues are identified.

\section{THEORETICAL FRAMEWORK}

\subsection{Advanced services}

A number of service typologies have been developed, which often extend Mathieu's (2001) SSP/SSC distinction; e.g., Ulaga \& Reinartz (2011) and Raddats \& Easingwood (2010). Baines \& Lightfoot (2013) use these typologies to define base, intermediate and advanced services, which are based on the SSP/SSC distinction, but provide a further delineation between the different types of offerings. More specifically, Baines \& Lightfoot’s (2013) typology facilitates differentiation between more complex advanced service offerings (where manufacturers' capabilities are utilized by customers and could feature risk and revenue sharing agreements) and less complex types of service offerings (e.g., the maintenance of competitors' products for a customer); both of which could be classified as SSCs, but create different contributions to customer value, with advanced services being acknowledged to offer higher levels of customer value on average than intermediate services, via improved performance, availability and reliability (Baines, Lightfoot \& Smart, 2011). This focus allows a more nuanced understanding to be developed.

Thus, advanced services address more complex, ongoing, requirements (Dachs, Biege, Borowiecki, Lay, Jäger \& Schartinger, 2014); which might have previously been addressed by more discrete offerings (e.g., 
Final version accepted for Publication

the sale of a product and some base or intermediate services). However, with the exception of a few researchers (e.g., Kohtamäki, Partanen, Parida \& Wincent, 2013) many studies assume equivalence between different types of services (Eggert, Hogreve, Ulaga, \& Muenkhoff, 2011; Evanschitzky, v.Wangenheim \& Woisetschlager, 2011); which does not reflect the possibility that they could differ in terms of processes and key capabilities required to deliver them. This research focuses on advanced services in order to extend our understanding of the capabilities needed to deliver these services both within the firm and across networks, allowing the development of context-specific theories and managerial understanding.

\subsection{Capabilities for advanced services}

This study draws on the resource based-view (RBV) of the firm by considering firms as bundles of resources and capabilities that when combined in a conscious and systematic way can provide firms with a strategic competitive advantage (Barney, 1991; Wernerfelt, 1984). To ensure that a multi-actor, dynamic, relational perspective of resource combination is taken, the study also incorporates the interaction, relationships and network view (Håkansson, Ford, Gadde, Snehota \& Waluszewski, 2009). Thus, a firm should be more successful if it aligns its resources and capabilities in such a way as to deliver sustainable value-creation strategies together with, and for, its counterparts within a value-creation network (Möller \& Rajala, 2007).

Capabilities refer to a firm's ability to deploy combinations of resources to achieve a desired goal (Amit \& Shoemaker, 1993), or the firm’s ability to perform productive activities (Jacobides \& Winter, 2012), with resources viewed as 'productive assets the firm owns' and capabilities as 'what the firm can do' (Ulaga \& Reinartz, 2011; Kohtamäki et al., 2013). Hence, we define firm capabilities as socially complex, combinations of interconnected resources that are deployed to achieve a desired end goal (Helfat \& Lieberman, 2002; Madhavaram \& Hunt, 2008), which can positively influence various performance measures, such as financial performance, competitive advantage and customer loyalty (Madhavaram \& Hunt, 2008). Day’s concept of ‘distinctive capabilities’ (Day, 1994) suggests that capabilities such as 
Final version accepted for Publication

'market sensing' and 'customer linking' may be seen as the foundation for the development of competitive advantage (Barney, Ketchen \& Wright, 2011; Helfat \& Winter, 2011) through the creation of value from the deployment of resources (Barney et al., 2011; Theoharakis, Sajtos \& Hooley, 2009). Further work classifies capabilities as operational capabilities, focused on how firms earn their living, and dynamic capabilities, how firms change their operational routines (Helfat \& Winter, 2011; Cepeda \& Vera, 2007). Advanced services require flexible, evolutionary implementation as manufacturers respond to customer needs, which are in turn driven by the evolving markets they face. Our focus is on the operational capabilities that support firms in earning a living in this space through developing and delivering evolutionary advanced services, rather than the mechanisms by which they change (dynamic capabilities). This is consistent with servitization research, where 'resource components' are combined into 'resource configurations' in order to deliver value to customers, supporting servitization success (Raddats et al., 2015), and network approaches, which emphasize the relational and managerial capabilities needed to manage heterogeneous networks (Möller, Rajala \& Svahn, 2005).

\subsection{Capabilities within network actors}

There is a recognition that competitive advantage can be derived from resources/capabilities that exist outside the firm, termed 'complementary assets' (Teece, 1986). Grönroos \& Helle (2010) and Prahalad \& Ramaswamy (2003), in particular, identify joint efforts with regards to productivity gains between actors (suppliers, intermediaries and customers) as a mechanism for mutual value creation. Furthermore, it is clear that this ability to create value stems from the complex interactions with other actors (Håkansson \& Waluszewski, 2013); and the combination of resources from manufacturers, suppliers and customers (Daliwal, Macintyre \& Parry, 2011; Kothandaraman \& Wilson, 2001; Möller\& Rajala, 2007).

For advanced services, it is more likely that firms will make use of their wider network for developing capabilities (Kindström \& Kowalkowski, 2014), since advanced services generally require providers to take over a customer's business process activities (Baines \& Lightfoot, 2013); an activity that is both costly and difficult. Therefore, while a manufacturer could pursue in-house development of capabilities, which can 
Final version accepted for Publication

offer a number of advantages with regards to competitive advantage (Nordin, 2008) and control (Paiola et al., 2013), it might also look to its wider network (Araujo et al., 2003; Spring \& Araujo, 2013), either via outsourcing or via co-developing capabilities with customers/partners (Paiola et al. 2013). This is consistent with Loasby’s (1998) idea of indirect capabilities - how good a firm is at accessing, but not controlling, other firms' capabilities. However, both options have disadvantages, such as the potential for a firm to become 'jack of all trades and master of none' if they go it alone, or the potential risks associated with opportunistic behaviors of business partners and an increase in co-ordination costs, if they utilize network actors (Håkansson \& Snehota, 1998). By studying the activities of network actors involved in the servitization process it may be possible to shed light on which service components might lend themselves better to internal or network-based capability development efforts (Davies, Brady \& Hobday, 2007).

There is also a growing body of research that suggests that network capabilities play an important role in the outcomes of servitization activities (e.g., Kohtamäki, et al., 2013). Network capabilities have been defined as “a firm's ability to develop and utilize inter-organizational relationships” (Walter, Auer \& Ritter, 2006: 541), and include such aspects as: network management (e.g., Smirnova, Naude, Henneberg, Mouzas \& Kouchtch, 2011); and integration and learning (e.g., Gebauer et al., 2013). A range of relational capabilities that underpin network capabilities have been identified; e.g., performance-enhancing relational capabilities (Lado, Paulraj \& Chen, 2011), alignment capabilities (Furlan, Grandnetti \& Camuffo, 2009), and relational value co-creation and innovation capabilities (Ngugi et al., 2010). Technology innovation capabilities have potential to play a key role in the functioning of interactions and relationships across networks via developments in digital information and communications technology (ICT) that can facilitate interactions and monitoring within relationships via smart communication between systems, assets and people that can also build barriers to entry (Baines \& Lightfoot, 2014; Baines, Lightfoot \& Smart, 2011; Bharadwaji, Varadarajan \& Fahy 1993; Day, 1994; Penttinen \& Palmer 2007). Furthermore, exploiting the increasing availability of 'Big Data' to improve insight for innovation is likely to require collaboration with actors possessing data management capabilities (Opresnik \& Taisch, 2015). What is of interest here is how downstream network actors support and complement the delivery of the manufacturer's new services. 
Final version accepted for Publication

Given that many manufacturers struggle to successfully servitize (Benedettini, Swink \& Neely, 2015;

Neely, 2008); unpicking what capabilities other network actors can contribute may well be key to understanding why some manufacturers succeed, while others struggle. For example, current work discusses the importance of a manufacturer developing a deployment capability (Ulaga \& Reinartz, 2011), but what is not yet clear is whether there are capabilities that customers or intermediaries need to develop, alongside this manufacturer deployment capability to ensure a successful outcome.

\subsection{Manufacturers' and Intermediaries capabilities}

Manufacturers typically derive competitive advantage from capabilities based on comprehensive product knowledge and intellectual property rights (IPR) facilitating the delivery of multiple product-related offerings, such as integration and deployment (Ulaga \& Reinartz, 2011). They also typically possess a reputational advantage, based on product heritage (Ceci \& Prencipe, 2008; Raddats et al., 2015). However, to offer advanced services, new capabilities are also needed (Antioco et al., 2008; Baines et al., 2009; Gebauer, Fleisch \& Friedli, 2005; Kowalkowski et al., 2011). Some work has been done to identify these capabilities. For example, developing a service culture (Neely, 2008; Ostrom et al., 2010); risk management (Baines \& Lightfoot, 2013), including developing and pricing services on a risk/reward basis (Baines \& Lightfoot, 2014; Cova \& Salle, 2008); and the ability to generate efficiency gains in service methodologies or processes that allow the manufacturer to offer the service more cheaply than the customer or other providers can provide them (Auguste, Harmon \& Pandit, 2006; Paiola et al. 2013; Storbacka, 2011).

Ulaga \& Reinartz (2011) and Paiola et al. (2013) suggest that manufacturers need to develop capabilities focused on understanding customers' service needs and aligning their offerings with customers' operational processes. Capabilities related to data processing and interpretation (Ulaga \& Reinartz, 2011) and design and innovation activities that support the development of new services (Auguste et al., 2006; Kindström \& Kowalkowski, 2014; Raddats et al., 2015) have also been identified. Finally, the centrality of relational capabilities is recognized (Ritter, 1999). Relational capabilities are supported by service personnel who 
Final version accepted for Publication

possess technical expertise, a strong customer focus (Gebauer, Edvardsson, Gustafsson \& Witell, 2010; Neu \& Brown, 2005) and knowledge of third party products (Raddats \& Easingwood, 2010). While interaction, relational and network capabilities have always been important for manufacturing firms, it is not yet clear how they are adapted and mobilized to facilitate the development of new capabilities that support servitization (Johnsen \& Ford, 2006; Ngugi, Johnsen \& Erdélyi, 2010; Ritter, 1999). Furthermore, given the scarcity of research into advanced services, there is a need to understand these capabilities, with regards to how they evolve within and outside an organization attempting to develop advanced services. However, in line with Ulaga \& Reinartz's (2011) notion of a 'hybrid' organization, it may also be important to study the extent to which historically-derived capabilities remain important; for example, product reputation or product innovation activities, and to understand the extent to which firms may need to balance the development of new capabilities alongside the maintenance of key product capabilities.

Manufacturers are likely to have strengths related to product knowledge that put them in a more competitive position compared to non-product intermediaries (e.g. Ceci \& Prencipe, 2008; Johnstone, Dainty \& Wilkinson, 2009) and may, thus, gain at the expense of intermediaries (Baines \& Lightfoot, 2013). However, it is not yet clear whether this assumption is true and, in particular, how true it is for advanced services, where it is possible that intermediaries could actually play an important role. For example, intermediaries may possess capabilities due to having an extensive service infrastructure local to customer sites (Oliva \& Kallenberg, 2003); or they may perform an important quasi-purchasing role for their customers, such as providing advice and suggestions for product acquisition and use (Olsson, Gadde \& Hulthén, 2013).

\subsection{Customer capabilities}

Customer interactions are one of the key episodes within any service delivery relationship (Bolton, Smith and Wagner, 2003; Håkansson \& Ford, 2002; Wilson, 2000). Furthermore, these interactions have a key role to play during servitization, in terms of customers' willingness to proactively discuss challenges and share comprehensive information regarding their operations, systems and processes (Selviaridis, Spring \& 
Final version accepted for Publication

Araujo, 2013). Thus, customers’ capabilities are likely to have a bearing on the capabilities a servitizing firm might need to have. For example, a customer strategy that emphasizes independence from product suppliers would require manufacturers to have less wide-ranging capabilities (and customers more wideranging capabilities); while a customer strategy that advocates outsourcing product-related activities to suppliers is likely to require a wider range of capabilities on the part of the manufacturer (Helander \& Möller, 2007). Indeed, Selviaridis et al. (2013) note that suppliers often need to support buyers during the specification of their service needs.

Tuli, Kohli \& Bharadwaj (2007) articulate the customer role through three customer variables: 'customer adaptiveness', the adaptation of internal routines and processes to accommodate suppliers' products and services; 'political counseling', helping suppliers to navigate the internal politics of the firm; and 'operational counseling', supplying operational information and guidance to suppliers. However, as yet, it is unclear how customers' capability development efforts may support manufacturers’ servitization efforts.

\subsection{Research Questions}

Thus, the overarching question for this study is: What capabilities are required for advanced services within a manufacturer and its downstream network? This is explored by considering three sub-questions:

a) What capabilities are required by manufacturers to facilitate the implementation of advanced services?

b) What capabilities are required by intermediaries to facilitate the implementation of advanced services?

c) What complementary capabilities are required by customers to facilitate the implementation of advanced services?

Table 1 identifies key categories of capabilities and examples of individual capabilities or strategies for their development already identified in the literature, as potentially necessary for advanced services. 
Final version accepted for Publication

Table 1: Capabilities for advanced services identified from the literature

\begin{tabular}{|c|c|c|c|}
\hline Actor & Theme of Capability & Source & $\begin{array}{l}\text { Examples of strategies for capability } \\
\text { development and/or capabilities }\end{array}$ \\
\hline \multirow[t]{13}{*}{ Manufacturers } & \multirow[t]{2}{*}{ Service innovation } & $\begin{array}{l}\text { Kindström \& } \\
\text { Kowalkowski } \\
\text { (2014) }\end{array}$ & $\begin{array}{l}\text { Twenty-four capabilities for service } \\
\text { innovation relating to } 8 \text { business model } \\
\text { elements: offering, revenue model, } \\
\text { development/sales/delivery process, } \\
\text { customer relationships, value network and } \\
\text { culture. }\end{array}$ \\
\hline & & $\begin{array}{l}\text { Ulaga \& } \\
\text { Reinartz (2011) }\end{array}$ & $\begin{array}{l}\text { Design-to-service capability-formulate } \\
\text { service components of offer early in the } \\
\text { innovation process. }\end{array}$ \\
\hline & \multirow[t]{3}{*}{$\begin{array}{l}\text { Influence of product } \\
\text { expertise }\end{array}$} & $\begin{array}{l}\text { Ceci \& } \\
\text { Prencipe } \\
\text { (2008) }\end{array}$ & $\begin{array}{l}\text { Firm's core business offering before } \\
\text { offering integrated solutions determines } \\
\text { existing capabilities and influences creation } \\
\text { of new capabilities. }\end{array}$ \\
\hline & & $\begin{array}{l}\text { Johnstone, } \\
\text { Dainty \& } \\
\text { Wilkinson } \\
\text { (2009) }\end{array}$ & $\begin{array}{l}\text { Strategic integration of services capabilities } \\
\text { alongside and with, existing product } \\
\text { capabilities (not a transition away from } \\
\text { products to services). }\end{array}$ \\
\hline & & $\begin{array}{l}\text { Raddats et al., } \\
\text { (2015) }\end{array}$ & $\begin{array}{l}\text { Reputation based on product manufacturing } \\
\text { heritage }\end{array}$ \\
\hline & $\begin{array}{l}\text { Services methodologies } \\
\text { and processes for } \\
\text { developing efficiency } \\
\text { gains }\end{array}$ & $\begin{array}{l}\text { Auguste, } \\
\text { Harmon \& } \\
\text { Pandit (2006) }\end{array}$ & $\begin{array}{l}\text { Firm should develop economies of scale } \\
\text { (high volumes, low variable costs and } \\
\text { intensive use of fixed assets) or skill } \\
\text { (developing process innovations and/or } \\
\text { identifying, deploying and replicating } \\
\text { scarce capabilities). }\end{array}$ \\
\hline & & $\begin{array}{l}\text { Paiola et al. } \\
\text { (2013) }\end{array}$ & $\begin{array}{l}\text { Firms develop capabilities to improve the } \\
\text { asset efficiency of customers and 'after- } \\
\text { sales solutions' providers aim to improve } \\
\text { efficiency by preventing failure of their } \\
\text { products within the customers' process. }\end{array}$ \\
\hline & & $\begin{array}{l}\text { Storbacka } \\
(2011)\end{array}$ & $\begin{array}{l}\text { Firm should develop rules for staff in order } \\
\text { to guide their creation of flexible solution } \\
\text { configurations for customer contexts that } \\
\text { decrease cost of sales and implementation. }\end{array}$ \\
\hline & \multirow{3}{*}{$\begin{array}{l}\text { Risk management, } \\
\text { mitigation and pricing } \\
\text { and delivery of } \\
\text { risk/reward contracts }\end{array}$} & $\begin{array}{l}\text { Baines \& } \\
\text { Lightfoot } \\
\text { (2014) }\end{array}$ & $\begin{array}{l}\text { Managing risk for advanced services } \\
\text { involving risk and reward sharing contracts }\end{array}$ \\
\hline & & $\begin{array}{l}\text { Cova \& Salle } \\
\text { (2008) }\end{array}$ & $\begin{array}{l}\text { Solutions involve the supplier managing } \\
\text { high risks }\end{array}$ \\
\hline & & $\begin{array}{l}\text { Ulaga \& } \\
\text { Reinartz (2011) }\end{array}$ & $\begin{array}{l}\text { Execution risk assessment and mitigation } \\
\text { capability }\end{array}$ \\
\hline & \multirow{2}{*}{$\begin{array}{l}\text { Understanding } \\
\text { customers' needs to } \\
\text { develop, sell, integrate } \\
\text { and deploy suitable }\end{array}$} & $\begin{array}{l}\text { Neu \& Brown } \\
\text { (2005) }\end{array}$ & $\begin{array}{l}\text { Developing learning relationship with } \\
\text { individual customers }\end{array}$ \\
\hline & & $\begin{array}{l}\text { Paiola et al. } \\
\text { (2013) }\end{array}$ & $\begin{array}{l}\text { Understanding customers' needs to develop } \\
\text { suitable service offerings }\end{array}$ \\
\hline
\end{tabular}




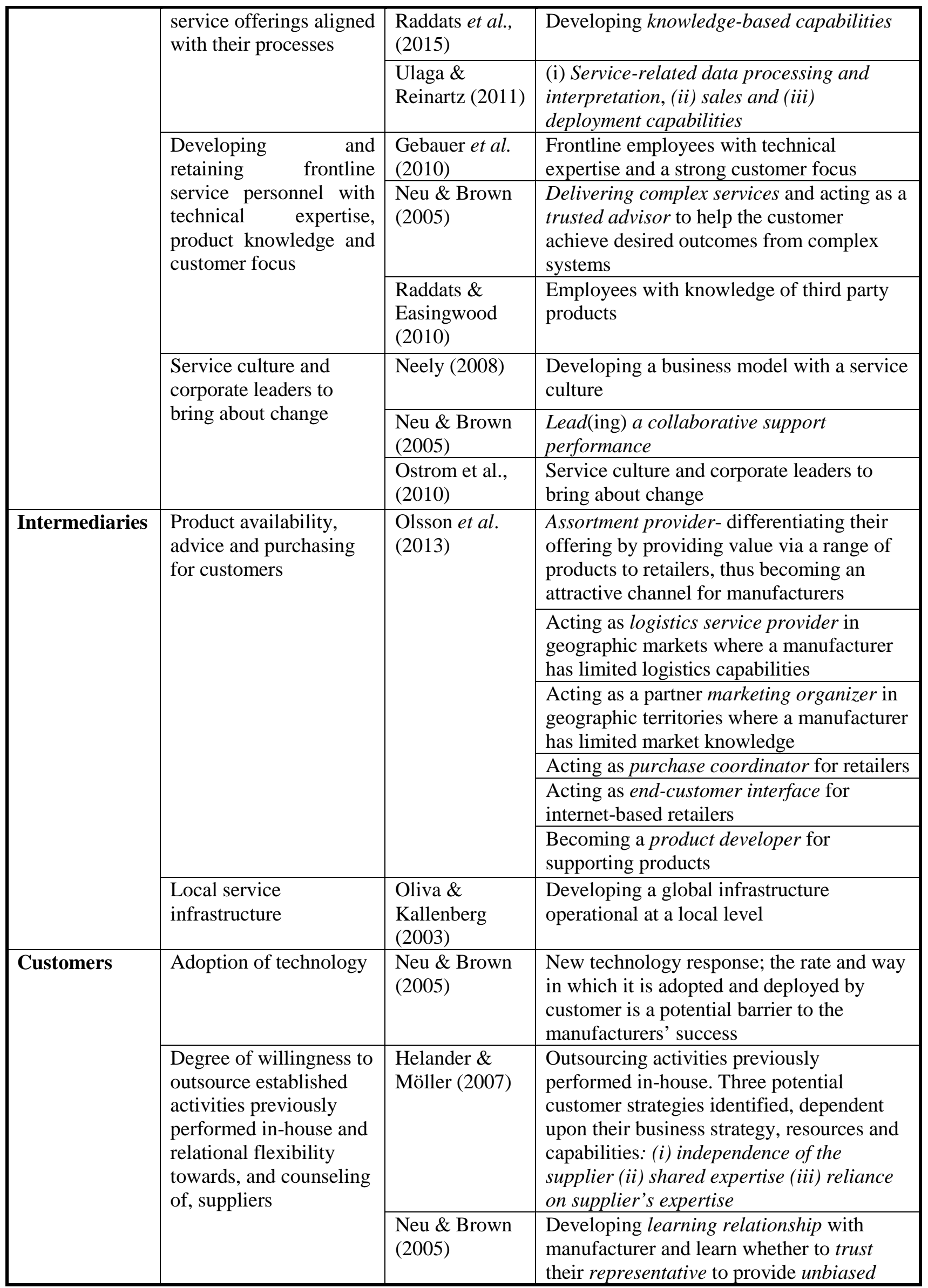




\begin{tabular}{|l|l|l|}
\hline \multirow{2}{*}{} & & advice \\
\cline { 3 - 3 } & $\begin{array}{l}\text { Selviaridis, } \\
\text { Spring \& } \\
\text { Araujo (2013) }\end{array}$ & $\begin{array}{l}\text { Customer willingness to discuss challenges } \\
\text { and share information regarding their } \\
\text { operations, systems and processes }\end{array}$ \\
\cline { 3 - 4 } & $\begin{array}{l}\text { Tuli } \text { et al. } \\
(2007)\end{array}$ & $\begin{array}{l}\text { Customer adaptiveness: Adaptation of } \\
\text { internal routines and processes to suppliers' } \\
\text { goods/services }\end{array}$ \\
& $\begin{array}{l}\text { Political counseling: to help suppliers } \\
\text { 'navigate' the customers' corporate } \\
\text { structures and political issues } \\
\text { Operational counseling: Supplying } \\
\text { operational information and guidance to } \\
\text { suppliers }\end{array}$ \\
\hline
\end{tabular}

\section{METHODOLOGY}

The purpose of this study was to investigate the capabilities that support the delivery of advanced services. The complexities of this topic led us to use a qualitative research methodology; such an approach is appropriate when there is a general lack of understanding of a phenomenon and an associated need for exploratory research to create improved understanding of the underlying causes of human action (Miles and Huberman, 1994). As these techniques are research intensive, a critical consideration was the choice of organizations to study. Respondents were therefore sought from UK B2B businesses in a range of sectors including health, transport and energy, who were: 1) associated with an organization either delivering (manufacturer, intermediary) or co-creating (customer) advanced services; 2) had themselves been involved with developing and delivering such services; 3) had knowledge and experience of a breadth of functions, e.g. marketing, operations; and 4) felt that they had some authority on this topic.

In order to establish reliability (Yin, 2014) we adopted the following procedures. In selecting the companies to take part in the study a 'stratified' purposive sampling approach was adopted (Bryman, 2008), with the aim of discovering capabilities across a range of manufacturers, intermediaries and customers involved with advanced services. This facilitated the identification of cases containing relevant information on the focal topic (Kemper, Stringfield \& Teddlie, 2003). Guided by the definition of advanced services adopted, organizations were deemed to be delivering or purchasing advanced services if there was evidence (through 
Final version accepted for Publication

a consideration of documentary evidence, such as websites and archival records) of them selling/purchasing service offerings that were complex bundles of products and services with on-going requirements, such as availability contracts. These service offerings involved features such as taking over (or outsourcing) customer core business processes, and the inclusion of risk/reward sharing with partners.

In some cases, the documentary evidence enabled us to identify customers that had adopted advanced services and intermediaries that were working with manufacturers to provide advanced services. However, while some potential intermediaries and customers were identified via this process, starting from manufacturers, all intermediaries and customers were approached independently of the manufacturers to determine whether they would take part in the study. Our unit of analysis was defined as: 'capabilities that support advanced services’. Thus, while we might have explored network constellations between multiple actors involved in co-creating these capabilities, we took as our focus each actor's view of their capabilities, independent from their specific interactions with other actors.

Managing Directors (MDs) (or equivalent) of the manufacturers and intermediaries were approached to confirm that the firm did indeed have a track record of delivering advanced services and, if appropriate, interviewed or asked whom should be interviewed within the organization. Additional personnel interviewed included Directors of: Strategy, Operations, Sales, Service Development (or similar). At the customer organizations, the MD or Operations/Supply Chain Director (or similar) were interviewed. Thus, a purposive sample was realized, consisting of high-profile industrialists likely to possess informed opinions on capabilities (for facilitating advanced services) created through an integrated network of actors, covering a range of contexts. Twenty-four senior executives were subsequently interviewed across 19 organizations; classified as manufacturers (7), customers (9) or as intermediaries (4), with one organization operating as both a customer and an intermediary (see Table 2). 
Final version accepted for Publication

Table 2: Interviewees' company sector, role and classification

\begin{tabular}{|c|c|c|}
\hline Company (sector) & Interviewee role & $\begin{array}{l}\text { Manufacturer (M), } \\
\text { Intermediary (I) or } \\
\text { Customer (C) }\end{array}$ \\
\hline 1 (Transportation) & Engineer Resource Support Operations & $\mathrm{C}$ \\
\hline 2 (Aviation) & Procurement Executive & $\mathrm{C}$ \\
\hline 3 (Telecommunications) & $\begin{array}{l}\text { Service Delivery Manager } \\
\text { Procurement Manager }\end{array}$ & $\mathrm{C}$ and $\mathrm{I}$ \\
\hline 4 (Transportation) & $\begin{array}{l}\text { Operations Director } \\
\text { VP, (Product) Life Services }\end{array}$ & $\mathrm{M}$ \\
\hline 5 (Energy) & $\begin{array}{l}\text { Service Manager } \\
\text { Operations Director }\end{array}$ & $\mathrm{M}$ \\
\hline 6 (Defense/aerospace) & Head of Supply Chain Capability & $\mathrm{I}$ \\
\hline 7 (Defense/aerospace) & UK Defense Collaboration Consultant & $\mathrm{M}$ \\
\hline 8 (Construction) & $\begin{array}{l}\text { Director of Equipment Solutions } \\
\text { GM, Product Support Operations }\end{array}$ & $\mathrm{I}$ \\
\hline 9 (Components) & CE, Automotive and Power & $\mathrm{M}$ \\
\hline 10 (Health) & Commercial and Strategy Director & $\mathrm{C}$ \\
\hline 11 (Transportation) & Group Board Director & $\mathrm{C}$ \\
\hline 12 (Defense/aerospace & Head of Platform Solutions & $\mathrm{M}$ \\
\hline 13 (Transportation) & Chief Executive Officer & $\mathrm{M}$ \\
\hline 14 (Defense/aerospace) & $\begin{array}{l}\text { Head of Commercial Support Solutions } \\
\text { Managing Director, Support Solutions }\end{array}$ & I \\
\hline 15 (Energy) & Site Manager & $\mathrm{C}$ \\
\hline 16 (Defense/aerospace) & Head of Service Research and Development & $\mathrm{M}$ \\
\hline 17 (Energy) & Plant Manager & $\mathrm{C}$ \\
\hline 18 (Local Government) & Head of Facilities & $\mathrm{C}$ \\
\hline 19 (Higher Education) & Director of Procurement & $\mathrm{C}$ \\
\hline
\end{tabular}

Given the position of respondents, an elite interviewing approach was adopted (Dexter, 2012; Welch et al. 2002). Based on the key literature identified in Table 1, independent semi-structured interview guides were developed for manufacturers and intermediaries and for customers, to explore the process of servitization 
Final version accepted for Publication

and the conditions facilitating the delivery of servitized offerings. This guide was applied in such a way as to encourage the interviewee to define and introduce relevant content where appropriate (Dexter, 2012) and to develop detailed, in-depth 'narratives' and 'stories' (Czarniawska, 2009; Gabriel \& Griffiths, 2004) of key servitization experiences and processes. Respondents from manufacturers and intermediaries were asked questions including: what advanced services are offered to customers?; what capabilities are required to develop and deliver these services?; what has changed in their practices and processes as a result of moving to advanced services?; what did they think they do well and from where do they derive their competitive advantage? Customer respondents were asked questions including: what were the motivations to adopt suppliers’ advanced services; what the business performance impact has been of adopting advanced services; what organizational changes have been made to accommodate the adoption of these services. This allowed us to explore the key business activities associated with servitization, outsourcing approaches of customers, the adaptations that they had made, and any new 'complementary' capabilities they might have developed. Interviews lasted between one and three hours and were audio recorded and transcribed, and shared with respondents in order to sense check and ensure that their views were fully represented.

Researchers then thematically coded the agreed versions of the transcripts using template analysis (King 2004). Initially, loose a priori capability codes, derived from literature (Dubois \& Gadde, 2002) (see Table 1), acted as a draft template. The template was then developed and expanded during the analysis, to include new categories that emerged from the data (Eisenhardt, 1989; King, 2004). The emerging capability themes were coded in parallel by two members of the research team via detailed reading and re-reading of the transcripts (Crabtree \& Miller, 1999; King, 1998). As recommended by King (2004), each researcher coded one of each type of interview transcript and, working from the key themes identified in the literature review and the data in their first transcript, created an initial template. Following King's (2004) approach, the two researchers then met, reviewed each other's suggestions, discussed, defined and justified their codes and agreed an initial template for application to the full data set. Each segment of text had the potential to be classified within multiple codes to allow for potential inter-relation of identified capabilities (King 2004). 
Final version accepted for Publication

The final coding structure was reached when further analysis of all the transcripts by the two coders brought forward neither new codes nor new relationships; that is, theoretical saturation was reached (Bryman, 2008). The emerging capabilities are presented in Section 4, as 'advanced services capabilities' (manufacturers and intermediaries) and ‘complementary capabilities' (customers), presented around a number of key overarching business activities: innovation, interaction processes, actor insight, business culture evolution, working with other actors and infrastructure development and management. The use of these overarching business activity headings allows us to structure our findings in such a way as to show the relationships between the manufacturer and intermediary capabilities and the complementary customer capabilities. The qualitative nature of the research and our exploratory position means we have adopted Creswell and Miller's (2000) position with respect to the validity of our data. Validity in this sense refers to the inferences drawn from the data. We have followed processes that allow us to establish the credibility of our study including reflection and peer review of our interpretations (Creswell and Miller, 2000; Hirschman, 1986) and in this way have confidence in the inferences presented.

\section{FINDINGS}

\subsection{Capabilities needed by manufacturers and intermediaries to facilitate the implementation of advanced services}

In line with prior work, the study revealed that manufacturers need to develop a range of capabilities to facilitate advanced services, aligned to both products and services. The intermediaries data also highlights that they require a number of capabilities, both to enable them to add value to manufacturers' offerings and to maintain position in the value chain. These capabilities are outlined below under related business activity headings. While the capabilities required by manufacturers and intermediaries are similar, their relative importance differs. For example, to add value to manufacturers' offerings, intermediaries focus on having a more extensive service infrastructure than manufacturers possess. These similarities and differences are also highlighted within each of the following sections. 
Final version accepted for Publication

\subsubsection{Innovation}

Being an innovator is recognized as being important for all firms. However, for manufacturers and intermediaries involved in developing advanced services there are some key areas that they should focus on in terms of innovation efforts. Thus, while prior research has identified the need for manufacturers to develop service innovation capabilities (e.g., Gremyr, Löfberg \& Witell, 2010), our data provides further evidence of types of innovation manufacturers need for advanced services. Central to these innovation activities is the need for manufacturers to develop the capability to 'balance product and service innovation' activities. In particular, there was evidence for manufacturers, that being a technology innovator was important for advanced services as it provides the platform to develop new offerings in terms of tools, processes and technology (Manufacturer 12). Innovation is also considered an important attribute for the manufacturers in terms of being able to understand how new technology could impact the customer's operational environment. Thus, service innovation will often start with new customer requirements; perhaps to reduce costs, provide finance or creatively price the offering:

“Our innovation has not necessarily been in making the next best 'mousetrap'; our innovation has come from fixed price service contracts” (Manufacturer [13], Transportation).

Innovation might also come from deploying ICT, such as web-based technology, including telemetry, which can enable a manufacturer to better manage the installed product base and react quickly in the event of outages or faults, thus improving the technical connections in the exchange relationship and facilitating the delivery of new services. For example, Manufacturer 13 (Transportation) has deployed telematics technology within a dealer network, to help jointly manage customers. Thus, a manufacturer's innovation might include technological advances, new services or contract redesign.

A key aspect of balancing product and service innovation activities relates to the ability to translate customer operational needs into a synergistic combination of product and service elements rather than just either considering product requirements with a base/intermediate service wrap or the service solution 
Final version accepted for Publication

without also considering the product requirements. The ability to maintain product innovation leadership alongside service innovation capabilities, where extant literature currently suggests moving to a solutionfocused approach based on service capabilities, seems to offer key competitive advantages for manufacturers. In terms of technology, the customer interviews suggests that they might prefer to work with manufacturers who have strong technology capabilities:

"We wanted to talk to the people who were investing huge amounts of energy and money in developing technologies...it allowed us to take advantage and benefit from that technology more quickly" (Customer [2], Aviation).

This supports Eggert, Thiesbrummel \& Deutscher's (2015), suggestion that 'hybrid' (rather than just product or service) innovations offer more successful servitization outcomes for manufacturers. The responses highlight the need to be able to create a balance between these technology trajectories with knowledge about customer requirements and potential profitability, to develop successful new services.

While the majority of data relating to innovation was manufacturer-centered, there was some evidence that intermediaries undertake small amounts of innovation, for example, through customizing standard products in order to better meet customer needs (Intermediary 14). However, we found little evidence that intermediaries were particularly focused on technological innovation beyond customizing activities. However, intermediaries were engaged to some extent in service innovation; for example, Intermediary 8 was investigating a new offering to monitor tires on the construction vehicles it supports. Thus, their innovation activity is skewed more towards service innovation and incremental adaptations, a capability we have termed - product and service modifications.

\subsubsection{Interaction processes}

Our data supports the idea that offering advanced services can require manufacturers to implement service methodologies that align to customers’ processes (Auguste et al., 2006; Paiola et al., 2013; Storbacka, 
Final version accepted for Publication

2011) developing the capability of 'customer-focused through-life service methodologies'. Technical product expertise must, therefore, be coupled with knowledge of how to best utilize products or productservice bundles in the context of the product-related activities customers need to perform, thus enabling manufacturers to gain capabilities related to customer processes. In doing so, manufacturers can give their customers a competitive advantage, not just from products but the service too:

\footnotetext{
"What (Manufacturer 7) has shown it could do with (Customer X) is show superiority through its ability to manage the availability of assets and effectiveness of assets through life. So even past the initial purchase, the ongoing capabilities that develop from that. What that does is give the customer the ability to differentiate and generate advantage. Not from the platform anymore but from the way it operates the platform and maintains the platform” (Manufacturer [7], Defense/aerospace).
}

Ultimately, manufacturers must be able to offer customers an improvement on what they can do themselves or what competitors can offer, in terms of cost, service quality (e.g., improving asset availability) and longterm asset management.

In terms of intermediaries, there is some evidence to suggest that they can create stronger service methodologies than manufacturers through working closely with the customer:

\footnotetext{
"When you start having to measure performance in a very granular way, because your contract payments are dependent on it, you have to have some robust data that represents a single version of the 'truth' that both the customer and provider can agree on in terms of contract performance". (Intermediary [6], Defense/aerospace).
}

Thus, while intermediaries might offer similar services to manufacturers, their service knowledge can enable them to better customize these services for customers through-life processes. This enables them to 
Final version accepted for Publication

win business from manufacturers by providing additional through-life value-add to the customer. They can also offer a range of services that manufacturers may not provide; for example, holding local stocks of spare parts with particular customers in mind. Thus, this capability, while seen in both manufacturers and intermediaries, seems to offer scope for intermediaries to draw on their traditional knowledge and skills to deliver additional value to customers.

\subsubsection{Actor insight}

While it is recognized that firms that are closer to their customers are likely to perform better than counterparts who are not as close (Goffin, Lemke \& Szwejczewski 2006), for manufacturers and intermediaries offering advanced services it appears that this closeness is vital; and that it goes beyond 'close', to essentially achieving an intimate understanding of their customers' needs and requirements - the capability of 'customer intimacy':

"The customer sees us as a key partner for them and together we are collaborating in a way that we don’t do with any of our other clients” (Manufacturer [5], Energy).

"You have to have some robust data... that represents a single version of the truth that both the customer and provider can agree on” (Intermediary [6], Defense/aerospace).

This intimacy allows manufacturers and intermediaries to understand the value their products and services have to the customer, beyond the actual cost of a component. To achieve this, these actors' account managers need to become extremely close to the customer to be able to understand what these needs and drivers are, in order to deliver effective solutions. Furthermore, our results suggest that building a customer intimacy capability is likely to deliver an important competitive advantage for intermediaries, e.g. Customer 1 in the transportation sector found that they were 'closer' to their intermediary than the manufacturer, with the intermediary better able to understand their business drivers and needs. Thus, intermediaries can use closeness to customers, to develop opportunities that manufacturers may be unable to exploit. 
Final version accepted for Publication

Thus, customer intimacy efforts appear to enable trusting relationships to build between manufacturer or intermediary and its customer, with deep relationships seen as an antecedent of future sales and the development of long-term revenue streams:

"It is not how big the contract is in the first instance, it is the relationship you have got.

You build from that relationship of trust, because then all the revenue streams can start to happen because you have a solid platform to work on” (Manufacturer [12],

Defense/aerospace).

Additionally, advanced services often involve the contractual relationship between the manufacturer or intermediary and customer changing, with 'gain share’ or risk/reward contracts more prevalent. Manufacturers and intermediaries, therefore, need the capability to be able to assess and manage risk for these offerings and price them in such a way that they are attractive to customers in terms of value offered, but are still profitable over the length of the contract:

"We have penalty and bonus systems based on mutually-agreed performance parameters, so number of days off the road. That might cause a penalty but it might cause a bonus if it's (the vehicle) off the road less often than is assumed and we can operate it more and generate more revenue accordingly” (Customer [11], Transport).

Thus, building a stronger understanding of risk management is particularly important for achieving customer satisfaction and acceptable profit outcomes from the implementation of advanced services, since the risks for both parties are higher. This is only really possible when manufacturers or intermediaries have intimate knowledge of their customers processes. 
Final version accepted for Publication

With increasing customer intimacy, intermediaries may be able to act as an 'honest broker' between customer groups, seeking opportunities through pooling requirements:

\footnotetext{
"The challenge for (manufacturer) and ourselves is how we can get these virtual communities together to widen the breadth of availability. Within an organization, especially large corporates, I think that can be done, it’s just the political will of doing it” (Intermediary [3], ICT supplying a local government managed print service customer).
}

It is equally important to be able to develop advanced services that provide customers with better value than they could achieve themselves. If manufacturers or intermediaries are not intimately acquainted with how the customer and other network actors operate, they will find it difficult to deliver a tailored offering that achieves this aim.

\subsubsection{Business culture evolution}

It is often argued that servitization efforts require manufacturers to develop a more service-orientated organizational culture. Indeed, Grönroos and Helle (2010), Oliva and Kallenberg (2003) and Sawhney, Balasubramanian, \& Krishnan (2004) all argue that only by managing the entire business from a service perspective, focused on supporting the customer's processes, will firms make the quantum leaps necessary to be successful. While our data clearly highlights that the intermediaries did not need to engage in business culture evolution because they already have a service-focused culture, we identified the need for manufacturers to develop a capability linked to business culture.

One of the main identified facets of developing a service culture is changing the mindsets of the workforce to become more service-focused. Results suggests that senior managers can support this cultural change by carefully re-positioning the company in the minds of all stakeholders and identifying potential blockages in terms of processes and reward structures that might inhibit the new culture from flourishing. However, in contrast to many studies, our data suggests that, even when developing advanced services, the requirement 
Final version accepted for Publication

for the whole organization to move to a more customer-focused service culture does not seem to be universal. In some cases these cultural changes were facilitated by having a dedicated services unit within a larger organization that focused on winning and managing service contracts, away from the need to be a support function for the company's products. Indeed, the idea of being self-sufficient (from the product side of the company) was stressed:

“Although we have links in terms of R\&D and new product development, we are almost selfsufficient in terms of technical skill sets within the service business, which makes us a very flexible and responsive organization” (Manufacturer [4], Transportation).

Thus, we can see that for most of our manufacturers, it is actually about maintaining some level of distinctness between the two groups in terms of culture. Our data also suggests that the necessary cultural change is likely to be facilitated by having multi-skilled engineers who are flexible in terms of the products they work on and the roles they perform. Thus, designing and implementing suitable service processes becomes not just a technical issue, but one requiring the recruitment of qualified engineers with the willingness and aptitude to work in a more service-oriented, customer-focused environment. Thus, it seems that a key element of the cultural change process may be to build strong, synergistic interfaces between the organization's product and service elements, through key boundary spanning individuals, who are able to harness the strengths of both product and service-focused specialists to deliver improved market offerings. With this in mind, we have labelled this capability 'distinct but synergistic product and service cultures'.

As one might expect, there is evidence that an established services culture offers competitive advantage for intermediaries; for example, Intermediary 3 is able to combine a document management availability contract with the telecommunications services it already provides to the customer. However, what is not clear from the data is whether this advantage is only temporary, until manufacturers manage to develop their service culture, or whether having this capability already would allow intermediaries some long-term advantage. 
Final version accepted for Publication

\subsubsection{Working with other actors}

Many advanced services require manufacturers to incorporate third-party products and service elements into their offerings (Raddats and Easingwood, 2010) and a fundamental capability of an intermediary is to work with manufacturers in order to supply products to their customers. While these relationships could be adversarial, our data suggests that this is not necessarily seen as the best approach, with manufacturers and intermediaries specifically choosing not to engage in competitive activities, even when they are able to do so, because they see more benefits from working with a preferred partner than from competing. Thus, we articulate a capability termed: 'coordination and integration of third party products/services':

\footnotetext{
"If you can bring smaller suppliers together, you can be the prime [service] through life provider. You can start to get a revenue stream not only from your own product but also a small handling fee for managing all the others. You can do it in the form of a service, so you are guaranteeing the number of flying hours, number of available aircraft, serviceability range, whatever your key performance indicators are” (Manufacturer [12], Defense/aerospace).
}

\footnotetext{
"We could go out and compete against them; however we elect not to. What we try and do is to develop our relationship with (the OEM) by being their preferred partner of choice". (Intermediary [14], Defense/aerospace).
}

However, the data also suggests that manufacturers actually build different relationships with actors, depending on what the actor brings to the service. This fits the ideas of Goffin et al. (2006) and Gebauer et al. (2013) with regards to only some partners becoming 'close'. It is also important that manufacturers recognize the value that intermediaries can bring to customers; for example, Intermediary 14 has negotiated access to manufacturers' intellectual property (IP) and undertakes minor product modifications for their 
Final version accepted for Publication

customers. Ultimately intermediaries would like to be seen as being able to offer the 'best' advanced services for a manufacturer's products (better than the manufacturer could offer):

“Nobody else can run this equipment more efficiently than we can, nobody else can provide the parts and the correct service provision better than we can, so it is a very unique position”. (Intermediary [8], Construction).

Thus, intermediaries must balance the requirement to work effectively with manufacturers while also carving out a distinct market position; so that manufacturers are unable to build direct customer relationships. The intermediaries ability to do so should help them to build their position in the network by developing this capability and thus, avoid 'value slippage’ (Lepak, Smith \& Taylor, 2007; Parry \& Tasker, 2014), whereby they give up value to other network actors.

In terms of manufacturers, being able to manage third party suppliers is a critical aspect of delivering advanced service offerings and something that can really add value to a customer, as it reduces their network management efforts. Furthermore, the data suggests that advanced services appear to require manufacturers to think more holistically about the type of companies they work with, since some of them might traditionally have been seen as competitors; and thus they need to consider the implications of coopetitive tensions that may arise in these situations (Bengtsson \& Kock, 2014). Decisions must, therefore, be taken about which actors to develop close relationships with and which to work with but keep at armslength. In line with Johanson \& Mattsson (1992), this ability to understand the network and to build and maintain a key position in the network seems to be a key capability for manufacturers and intermediaries in terms of being able to appropriate value from within the network.

\subsubsection{Infrastructure development and management}

Particularly crucial for the delivery of advanced services is the capability of manufacturers and/or intermediaries to provide services where the customer needs them. One of the most effective capabilities 
Final version accepted for Publication

that our intermediaries have for maintaining their position in the network is their ability to have a dispersed service infrastructure close to the customer, that is able to deliver continuity of service provision. Together these resources combine to create a 'Localized service delivery' capability:

\footnotetext{
"We see it as being important to participate more locally, closer to our customers and we are benefiting from that.” (Manufacturer [5], Energy).
}

\begin{abstract}
“Smaller organizations, or even larger organizations, only have a few people on a remote site. Having holiday cover, sickness cover and all of those aspects, keeping up to date with the training, they are having issues with retaining skills". (Intermediary [8], Construction).
\end{abstract}

Scaling service infrastructure to offer services over a large geographic area appears to be a fundamental part of this capability. Actors who achieve this can secure a strong position in the service delivery value chain. However, the idea that servitization is about manufacturers getting closer to the customers, implies that intermediaries would get 'squeezed out' (Kohli, 2011). Our data actually shows that service infrastructure provision is often a role performed by intermediaries, because the costs involved in building such infrastructure can be prohibitively expensive for manufacturers. This suggests that servitization success may well be partially based on the complementarity of manufacture/intermediary capabilities, highlighting a need to understand how manufacturer and intermediary capabilities might combine.

\title{
4.2 Complementary capabilities required by customers to facilitate advanced services
}

The data indicates that value outcomes are less likely to be optimized if only manufacturers and intermediaries develop capabilities and that customers, therefore, also need to develop complementary capabilities. These are presented under the six key business headings.

\subsubsection{Innovation}


Final version accepted for Publication

Whilst technological advances will generally come from manufacturers, innovation, in terms of new services or contract design in particular, can sometimes come in the form of joint development between a supplier and a customer. This involves the customer developing a complementary capability, termed: 'cocreating innovation'. For example, Customer 19 (Higher Education) is working with a document management supplier to facilitate new ways to print from mobile devices. Customer 11 developed an innovative approach to service design and pricing with a transportation sector manufacturer, based on a price-per-mile for the fleet of vehicles, rather than one-off purchases of the vehicles and servicing. Customer 11 also highlights that they use this approach to charge their customers, so they can match income and costs to ensure the profitability of the service.

Customers, therefore, may well need to build an innovation capability to work with manufacturers, both from a technological perspective, but also in terms of new service and contract design. What is interesting here, is that customers would need to retain some innovation expertise in-house to be able to engage in these activities:

\footnotetext{
"We are not just going to listen to what the current provider tells us. They will build something new, tell us it's wonderful and try and sell it to us. Do we actually want it? Is it any good to us? So, we are not going to listen just to them, we will also look at what else is available in the market” (Customer [18], Local Government).
}

Thus, customers need a complementary innovation capability to work with their supply chain. This enables both the manufacturer and customer to obtain more value from the advanced services offering developed and ensures that customers are able to judge what the 'best' services option is for them.

\subsubsection{Interaction processes}

Our data suggests a need for customers to adapt their existing operational processes, to align with the customer-focused service methodologies of manufacturers and intermediaries. This complementary 
Final version accepted for Publication

capability is labelled: 'processes supporting service outsourcing'. Setting up outsourcing contracts is not simply a matter of choosing an operational process and getting an external provider to run it:

\footnotetext{
"You cannot just sell off services and expect someone to run them. You need to sort yourself out first, before you know what you are procuring” (Customer [18], Local Government).
}

Thus, customers may need to develop stronger process methodologies themselves and do some up-front work on understanding their processes before they commit to a service contract. This is particularly important given the complicated nature of specifying the right details of the contract. This accords with Martinez, Bastl, Kingston \& Evan’s (2010) notion of customers and suppliers moving together in their servitization efforts. This understanding is important in terms of meshing the outsourced provision with internal processes:

\footnotetext{
"We servitized all the components of the printing that go on in the University and gradually wove those into a service provision or an outsource”. (Customer [19], Higher Education).
}

One of the complications of outsourcing, from the customer's perspective, is risk management, with the need to balance service cost (achieve the lowest possible price) while minimizing risk, to obtain an optimal outcome. These efforts, related to the need for other actors to develop service methodologies capabilities, are also then useful in working more closely with manufacturers to produce optimum service processes. This suggests that customers should not reach a decision to purchase services from a manufacturer and/or intermediary and then just passively accept the terms and processes offered. Instead, they need to maintain processes that allow them to work with the provider to help maximize internal efficiencies and value gain from advanced services offerings. 


\subsubsection{Actor insight}

Manufacturers and intermediaries clearly need to develop intimate relationships with their key customers. However, the results suggest that customers need to develop a complementary capability of 'managing risks associated with developing intimacy with external actors', with evidence that a more intimate knowledge of each other enables suppliers and customers to work together more effectively, perhaps to look for new opportunities. For example, customer 10 (Health) is using one of its supplier’s commercial and bidding expertise to tender for new work from other healthcare providers. However, while it is clear that customers need to build open relationships to enable intimacy, interviewees also stressed the need to manage their suppliers to prevent them getting complacent:

\footnotetext{
“It is about supplier management, and keeping the suppliers 'on their toes' so that they do not get into that 'comfortable space'. You want them comfortable, but not too comfortable” (Customer [3], Telecommunications).
}

It is, therefore, clear that customers need to balance intimacy, and all the benefits that this brings, with careful consideration of key contractual aspects of these relationships, which can be particularly complex for advanced services. Customers benefit from strong, close relationships with their key suppliers, but they also need to ensure that these suppliers do not become complacent, or take advantage of the closeness that develops. This supports the view of Håkansson \& Snehota (1998) that relationships are not free from risk or without burden, thus, customers need to be capable of managing these risks well.

\subsubsection{Business culture evolution}

As outlined earlier, to offer advanced services manufacturers need to develop a stronger service culture. The data suggests that customers also need to have, or to develop, a culture that embraces change and builds a mind-set that includes cooperative and communicative values (Barnett, Parry, Saad, Newnes \& 
Final version accepted for Publication

Goh, 2013). This is the complementary capability of: 'outsourced-service evaluation'. This change typically comes from outsourcing activities that might have previously been performed in-house. Therefore, one of the most significant challenges from the customer's perspective is assessing each aspect of its business to determine whether it is best performed in-house or by an external provider. As with manufacturers developing a service culture, this change in customers' culture needs to be driven by senior management. Leadership to introduce change in an organization is only one part of the equation though, with procurement professionals needed who have expertise in setting up and managing outsourcing contracts:

\footnotetext{
"You don’t need to spend £5 billion to be good at outsourcing or to have the experience but frankly you do need to have spent something... I know every problem in an outsource because I’ve either caused them or fixed them” (Customer, [19], Higher Education).
}

Cultural change is, therefore, not just something manufacturers need to embrace; customers also need to be ready to adapt internal processes and mind-sets in order to obtain the best value from the advanced services they buy. However, they also need to be clear about what their core business is and what should be provided by external providers.

\subsubsection{Working with other actors}

In terms of the customer's role with regards to partnering; the question customers need to ask themselves is, 'if manufacturers have a range of capabilities then what capabilities do we need to retain in-house?' The data suggests that customers will sometimes retain in-house (complementary) capabilities; 'maintaining procurement expertise'- to service their own equipment fleet, without significant assistance from manufacturers or intermediaries. Clearly, customers need to understand where they can perform a role sufficiently well themselves and where they might need to engage with partners. When they do look to the network to provide services, the complexities of procuring multi-vendor equipment means that it is important that they retain in-house procurement expertise: 
Final version accepted for Publication

\begin{abstract}
"I have two or three very good expert engineers, who help me make decisions, who can go and really challenge (Manufacturer) on their decision making. Because of that in-house type of understanding and capability, I feel quite strong when we negotiate with them” (Customer [15], Energy).
\end{abstract}

Retaining some in-house multi-vendor capabilities might be important to customers and certainly the ability to procure these capabilities is a key area of expertise that customers need to build in order to have any negotiation power in the network.

\title{
4.2.6 Infrastructure development and management
}

Some customers retain service infrastructure capabilities and thus, are able to match their service infrastructure capabilities with those of the manufacturer/ intermediary, so if the latter has greater scale then the former might need less (supporting Helander \& Möller, 2007). The data suggests that maintaining some service infrastructure capabilities, a complementary capability we have termed 'appropriate retention of service infrastructure', allows customers to support the service delivery process; for example, in-house providers to service older products and external providers to service newer technology. If both internal and external providers are used, then it becomes necessary to balance their use, to ensure that both have sufficient work to maintain investment in the required resources.

It is also clear that customers remain acutely aware of the importance of maintaining appropriate coverage with regards to service infrastructure and that they select actors based on their ability to deliver this coverage:

"We need to make sure that there is a network of service stations that covers the whole country because we don’t want to go too far” (Customer [11], Transportation). 
Final version accepted for Publication

Thus, customers need to consider their own service infrastructure resources and how to match these with a supplier's service infrastructure and create the optimum balance of coverage to cost. It is also possible that developing this capability might act as a competitive advantage, in terms of who they are able to work with.

\subsection{Unique and critical capabilities for advanced services}

An important question is how unique and critical these capabilities are to each actor's servitization efforts in terms of advanced services? To answer this question, each actor will be considered in turn, with those capabilities that are unique and critical, highlighted below. A number of other capabilities, identified in Table 3, are important, but are not unique to advanced services; for example, customer intimacy (manufacturers and intermediaries) is a normative goal in many B2B relationships, not just ones based on advanced services. Equally, a culture of outsourced service evaluation (customers) is again important for all service outsourcing, not just for servitizing firms.

For manufacturers, three capabilities were viewed as unique and critical for advanced services, outlined in the following propositions:

Proposition 1: Manufacturers need to balance product and service innovation, since without service innovation manufacturers are only likely to be able to offer base and intermediate services (not advanced services).

Proposition 2: Customer-focused through-life service methodologies are particularly important for manufacturers in terms of developing risk/reward service contracts, since these are a critical component of advanced services. 
Final version accepted for Publication

Proposition 3: Creating distinct, yet synergistic product and service cultures is one of the greatest challenges of servitization, since it requires changing organizational mindset from a product-, to a productand service-focus.

For intermediaries, the only capability that is unique and critical for advanced services is:

Proposition 4: Intermediaries need coordination and integration of third party products/services, since their business models rely on forming relationships with third party suppliers and then using knowledge from these relationships to be informed providers of products and services to customers.

For customers, two capabilities are unique and critical for advanced services:

Proposition 5: Co-creating innovation is particularly important, since advanced services may involve changing the basis of a provider's offerings, from product supply with base/intermediate services to, for example, an availability contract. Thus, customers and suppliers need to jointly develop the new offerings.

Proposition 6: Having processes supporting service outsourcing enable the management of internal/external service provision to ensure the efficient delivery of key operational processes. While service outsourcing is common in many businesses, the inclusion of product-related processes makes this a unique capability that customers need to develop.

Table 3 summarizes the key capabilities for advanced services required by each actor and the six propositions of unique and critical capabilities are shaded grey. 
Table 3: Summary of the key capabilities by manufacturer, intermediary and customer (unique/ critical capabilities for advanced services shaded)

\begin{tabular}{|c|c|c|c|}
\hline & \multicolumn{2}{|l|}{ Capabilities } & \\
\hline Key Business Activities & Manufacturer & Intermediary & Customer (Complementary) \\
\hline Innovation & $\begin{array}{l}\text { Balance product and service innovation } \\
\text { - Identifying customer operational } \\
\text { requirements } \\
\text { - Deploying ICT } \\
\text { - Synergistic combining of product and } \\
\text { - } \text { service elements } \\
\text { - Technological roadmaps/innovation }\end{array}$ & $\begin{array}{l}\text { Product and service modifications } \\
\text { - } \quad \text { Customization of standard products } \\
\text { - Service extensions to existing } \\
\text { offerings }\end{array}$ & $\begin{array}{l}\text { Co-creating innovation } \\
\text { - New service and contract redesign }\end{array}$ \\
\hline $\begin{array}{l}\text { Interaction } \\
\text { Processes }\end{array}$ & $\begin{array}{l}\text { Customer-focused through-life service } \\
\text { methodologies } \\
\text { - Understand how customers use } \\
\text { - } \text { products operationally } \\
\text { - Develop risk/reward service contracts }\end{array}$ & $\begin{array}{l}\text { Customer-focused through-life } \\
\text { service methodologies } \\
\text { - Understand how customers use } \\
\text { products operationally } \\
\text { - Customization and value-added } \\
\text { services } \\
\end{array}$ & $\begin{array}{l}\text { Processes supporting service } \\
\text { outsourcing } \\
\text { - Adaptation of existing operational } \\
\text { processes } \\
\text { - Management of internal and } \\
\text { external provision } \\
\end{array}$ \\
\hline Actor Insight & $\begin{array}{l}\text { Customer intimacy } \\
\text { - Understand product value in terms of } \\
\text { customer use/drivers } \\
\text { - Detailed understanding of customer } \\
\text { processes }\end{array}$ & $\begin{array}{l}\text { Customer intimacy } \\
\text { - Heightened customer intimacy- } \\
\text { very close relationships with } \\
\text { customers }\end{array}$ & $\begin{array}{l}\text { Managing risks associated with } \\
\text { developing intimacy with external } \\
\text { actors } \\
\text { - Supplier intimacy with key } \\
\text { - Providers } \\
\text { - Professional contract management }\end{array}$ \\
\hline $\begin{array}{l}\text { Business culture } \\
\text { evolution }\end{array}$ & $\begin{array}{l}\text { Distinct, yet synergistic product and } \\
\text { service cultures } \\
\text { - Dedicated service unit } \\
\text { - Multi-skilled engineers }\end{array}$ & $\begin{array}{l}\text { Not necessary: already service- } \\
\text { focused }\end{array}$ & $\begin{array}{l}\text { Outsourced-service evaluation } \\
\text { - Culture that embraces change } \\
\text { - Leaders and procurement } \\
\text { professionals to drive change }\end{array}$ \\
\hline $\begin{array}{l}\text { Working with other } \\
\text { actors }\end{array}$ & $\begin{array}{l}\text { Coordination and integration of third } \\
\text { party products/services } \\
\text { - Using intermediaries to add value for } \\
\text { the customer }\end{array}$ & $\begin{array}{l}\text { Coordination and integration of } \\
\text { third party products/services } \\
\text { - Balancing relationship with } \\
\text { manufacturer(s) while } \\
\text { defending unique market } \\
\text { position } \\
\end{array}$ & $\begin{array}{l}\text { Maintaining procurement expertise } \\
\text { - Retained product/process } \\
\text { knowledge after outsourcing to } \\
\text { support future procurement }\end{array}$ \\
\hline
\end{tabular}


Final version accepted for Publication

\begin{tabular}{|c|c|c|c|}
\hline & & $\begin{array}{l}\text { Offering multi-vendor } \\
\text { products/services }\end{array}$ & \\
\hline $\begin{array}{l}\text { Infrastructure } \\
\text { development and } \\
\text { management }\end{array}$ & $\begin{array}{l}\text { Localized service delivery } \\
\text { - Developing scale and customer } \\
\text { proximity of service infrastructure } \\
\text { - Competitive intelligence (on } \\
\text { intermediaries/customer) capabilities } \\
\text { - Appropriate investment } \\
\text { - Ability to understand and calculate } \\
\quad \text { /coverage implications } \\
\end{array}$ & $\begin{array}{l}\text { Localized service delivery } \\
\text { - } \\
\text { peveloping customer } \\
\text { infrastructure } \\
\text { - Extensive facilities } \\
\text { - } \\
\text { Service continuity }\end{array}$ & $\begin{array}{l}\text { Appropriate retention of service } \\
\text { infrastructure } \\
\text { - Align own infrastructure with } \\
\text { - external providers' } \\
\text { - Understanding of coverage issues } \\
\text { - Appropriate investment } \\
\text { - Ability to calculate cost/coverage } \\
\text { implications }\end{array}$ \\
\hline
\end{tabular}


Final version accepted for Publication

\section{CONCLUSIONS}

\subsection{Implications for theory}

The study investigates manufacturer, intermediary and customer perspectives on the capabilities necessary for successful servitization; focusing on the downstream capabilities that network actors need to establish, in order to successfully develop and deliver advanced services. In addressing this aim, we identify the capabilities required by these three different actors, which align to six key business activities. In particular, we highlight those capabilities that are unique and critical for advanced services. In doing so the study makes three main contributions.

First, while previous studies have identified servitization capabilities (e.g., Raddats et al., 2015; Ulaga and Reinartz, 2011), this study specifically addresses advanced services capabilities and provides six propositions of capabilities that appear unique and critical for advanced services. From a manufacturer's perspective, three of these capabilities are unique and critical (propositions 1-3); for example, balanced technological and service innovation (Eggert et al., 2015). Service innovation, is particularly, critical (Kindström \& Kowalkowski, 2014; Ulaga \& Reinartz, 2011), because advanced services require manufacturers to undertake new activities which are, in some respects, alien to them, such as developing offerings that extend product lifecycles. Equally, the ability to develop customerfocused through-life service methodologies, which include a risk/reward element, is a critical capability for advanced services (supporting Baines \& Lightfoot, 2014; Cova \& Salle, 2008), since contracting on this basis may represent a fundamentally new way of working for many manufacturers. Another critical capability for advanced services is the ability to develop a distinct, yet synergistic service culture (Neely, 2008; Ostrom et al., 2010), possibly facilitated by using a dedicated service business unit (Salonen, 2011) and employing multi-skilled engineers (Gebauer et al., 2010). Once again, a manufacturer’s traditional product focus can make this a necessary but very challenging transformation and one that manufacturers only providing base and intermediate services may not have to make. In addition to these three unique and critical capabilities, three others were identified 
Final version accepted for Publication

for manufacturers: customer intimacy, required to better understand their needs and develop suitable service methodologies including developing knowledge based capabilities through learning relationships with customers (Neu \& Brown, 2005; Raddats et al., 2015); developing relationships with other network actors in order to facilitate coordination and integration of third party products/services (Baines \& Lightfoot, 2013; Raddats \& Easingwood, 2010); development of a service infrastructure, close to key customers, in order to provide localized service delivery.

Second, we consider capabilities from the perspective of both the manufacturer and intermediary. In doing so this study extends our understanding of the capabilities required for servitization, which tend to only be considered from the perspective of the focal manufacturer, rather than the multi-actor approach used in this study. While the role of intermediaries has been briefly discussed (e.g. Ulaga \& Reinartz, 2011), some prior work generally assumes them to simply be a channel for manufacturers' offerings, taking on the provision of local infrastructure (Ford et al., 2003). The focal manufacturer perspective might tend to suggest that manufacturers gain while intermediaries lose, but we have found examples where intermediary actors have survived and thrived by developing capabilities that have allowed them to offer additional value. Our data suggest that intermediaries can also be distinct actors, with their own agenda. What is clear in this study is that different actors in the network are all looking to maintain their position within it and the ability to perform well in the network seems crucial for generating value (revenue growth) from servitization efforts. Furthermore, while there are some similarities between the capabilities required by these two groups, there are also differences in the relative strength of each one and the resources required to achieve them. Intermediaries were less likely to create technological innovation than manufacturers, although they were still likely to undertake service innovation. Intermediaries were more likely to customize their service methodologies to customer needs and seek intimate customer relationships, to overcome their (typically) shallower product-based technical knowledge. Intermediaries were also more servicefocused businesses, adept at developing relationships with manufacturers and providing multi-vendor technology to fit the needs of their customers. Indeed, this capability appears particularly critical for 
Final version accepted for Publication

intermediaries (proposition 4) in terms of servitization, since being able to offer the most suitable multi-vendor products within an advanced service could be a real differentiator compared to what manufacturers can provide, helping to provide customers with independent product advice (Olsson et al., 2013). Finally, intermediaries often built cost-effective infrastructure close to their customers (Oliva \& Kallenberg, 2003), which some manufacturers were not willing or able to do.

Third, the data suggests that there are a number of complementary capabilities that customers may need to have in order for servitization efforts to succeed; two of them unique and critical for advanced services. This idea of complementary capabilities has been raised before, both in terms of ideas relating to co-creation (Vargo \& Lusch, 2008; 2011) and to a limited extent in the solutions literature (Helander \& Möller, 2007; Tuli et al., 2007). Fundamentally, our study highlights the need for customers to work with suppliers to innovate, so that new offerings can be successfully implemented (proposition 5). The data also suggests that customers need to engage in process changing activities, such as adapting their processes to better dovetail with those of the other network actors (Helander \& Möller, 2007) in order to support service outsourcing (proposition 6). In addition to these servitization specific capabilities, customers need to develop a culture of outsourced-service evaluation; being open, in terms of information sharing with key suppliers (Tuli et al., 2007) and examining which activities might be better undertaken by external providers. Even if some activities are outsourced, customers need to take a proactive, co-creating role in service design/innovation and implementation, whilst at the same time maintaining procurement expertise by retaining key internal knowledge capabilities, such as procurement/contract management and product/technology knowledge, to ensure that they are not disadvantaged when it comes to procuring and designing new services. Finally, customers should also develop capabilities in terms of managing risks associated with developing intimacy with external actors, and managing internal and outsourced service infrastructure to obtain the best value outcome from these combined resources. 
Final version accepted for Publication

It is clear from this study that many of the capabilities that each actor develops are in themselves complementary and sometimes overlapping and that developing just some of the capabilities is insufficient to be successful. In the same way that capabilities are seen to be socially complex, combinations of interconnected resources that are deployed to achieve a desired end goal (Helfat \& Lieberman, 2002; Madhavaram \& Hunt, 2008); it is likely that sustainable competitive advantage may be achieved through the complex combinations of interconnected capabilities found within manufacturers, intermediaries and customers.

\subsection{Implications for practice}

The research suggests a number of important managerial implications for manufacturers, intermediaries and customers concerning advanced services capabilities. Manufacturers need to balance product and service innovation; so while product innovation may be the norm, service innovation is also critical, and will often take place within the customer domain, rather than through traditional research and development activities within the manufacturer. Manufacturers, therefore, need to empower account teams to seek out new service opportunities and be able to bring them to fruition within the company. Manufacturers also need to invest in appropriate methodologies and technologies, to enable the provision of advanced services (potentially supported or delivered by smart ICT) that improve upon the customers' own internal processes. Fundamentally, a clear senior managerial lead is required to undertake the cultural change to a more services-focused business, repositioning the manufacturer as a provider of advanced services in the eyes of its key stakeholders, but without losing product-based capabilities. This might be achieved by recruiting suitable services personnel and even the creation of a distinct service-focused business unit responsible for developing and selling service offerings and coordination of the firm's service efforts. Manufacturers might also need mechanisms to help customers to develop their own capabilities in order to facilitate advanced service co-development and processes to support service outsourcing. 
Final version accepted for Publication

Manufacturers and intermediaries possess different combinations of capabilities for the provision of advanced services. For example, manufacturers have deep product knowledge, while intermediaries have extensive local infrastructure (that can make them a more cost effective delivery mechanism for advanced services) and very close customer relationships. Of particular note for advanced services is the ability of intermediaries to facilitate relationships with a range of other manufacturers to develop and deliver multi-vendor offerings to customers. By working together manufacturers and intermediaries can help to overcome any weaknesses in each other's capabilities to provide comprehensive advanced services to their customers. Intermediaries will benefit from understanding where they may need to work closely with manufacturers (for example, to access IP) and where they may benefit from keeping manufacturers at arms-length (for example, helping their customers to select the most appropriate services from a range of manufacturers). Intermediaries should also establish where their most effective competitive advantages come from and focus on maintaining or extending their capabilities in these areas - for example, where proactive investment in local infrastructure might put off manufacturers from attempting to develop their own .

While customers may value the expertise that manufacturers, intermediaries or a combined network can provide, they are only likely to want these advanced services if they offer clear benefits over what can be provided in-house. To bring this about, customers will almost certainly have to work closely with providers to create these new offerings and share product performance data and operational costs. They also need a willingness to outsource operational activities. However, they still need to retain some product knowledge and purchasing expertise in order to be able to properly judge the value of potential advanced services offered by providers. If customers do not possess these critical complementary capabilities, then manufacturers or intermediaries wishing to provide advanced services may hit problems when trying to sell and deliver new advanced services to these customers. Ultimately, not every customer may want, or have the capabilities to successfully procure advanced services; so manufacturers could use these capabilities as a basis of customer segmentation, providing appropriate offerings (base, intermediate, advanced) to different groups. Alternatively, this 
Final version accepted for Publication

segmentation exercise might also lead to manufacturers realizing a need to proactively support the development of complementary customer capabilities in particularly important customer segments.

\subsection{Limitations and future research}

As with all research, this study has a number of limitations. Previous confirmatory research has identified that servitization capabilities for manufacturers are similar across different sectors (Raddats et al., 2015). This exploratory study, therefore, considered the capabilities possessed by a range of actors in multiple industrial sectors, rather than focus on nuanced aspects of capabilities from within a single actor or sector. Further research could extend the sample by focusing specifically on single actors (intermediaries or customers) or sectors. Although data was collected from a fairly large sample, because the sample was purposively developed, the findings cannot be generalized to the population. Furthermore, while the focus of this study was on capabilities for advanced services, we acknowledge that, for many manufacturers, base and intermediate services may be more applicable. Our findings are, therefore, limited to organizations for whom advanced services are applicable. Future research might take a confirmatory approach and operationalize the identified constructs in the six propositions proffered, to provide further evidence of the phenomena studied. Additionally, some of the companies in the study are part of the same networks. We do not believe that this issue affected the results since the study investigated actor-specific capabilities, rather than capabilities related to the specific interactions between network partners. However, we accept that this use of multiple actors from within the same network might have led to identification of co-created capabilities, developed through interaction, which could hinder discrete and independent analysis of what they are. It is also possible that where multiple actors in a network were willing to engage in the study, this could reflect contexts where capabilities for servitization may be different in some way from those where only one actor engaged in the study. For example the former might be, more established, more effective or more easily recognized by actors. In turn this may influence the ease with which respondents could identify and discuss the characteristics of the capabilities. We acknowledge that future studies could go further than we have with regards to developing understanding of a multi-actor perspective; 
Final version accepted for Publication

specifically investigating capabilities in dyadic or network relationships. This would allow them to consider relational capabilities, specifically how actors in the same network develop capabilities in response to each other's capabilities, provide in-depth data encompassing multiple views of the same capabilities and better establish how capabilities 'fit together'.

We were successful in negotiating access to manufacturers and customers; but did not access as many intermediaries. This may, in part, be due to the fact that, because servitization activities are argued to involve manufacturers taking over processes previously provided by intermediaries, intermediary involvement can, therefore, be expected to be lower. Furthermore, accessing intermediaries can be challenging as they may be wary of giving away knowledge; because the focus of servitization is about how manufacturers get closer to customers, thus, threatening intermediaries' key business. Nevertheless, having fewer intermediaries in the study means that it is very likely that additional capabilities for advanced services might exist within this group. Future studies could focus more on intermediaries and customers to gain a better understanding of their capabilities and role within the servitization process. Future research should also investigate further, how independent actors collaborate and integrate their resources, including new smart technologies supporting monitoring and connectivity, to develop effective network capabilities. 
Final version accepted for Publication

\section{REFERENCES}

Amit, R. \& Shoemaker, P. (1993). Strategic assets and organizational rent. Strategic Management Journal, 14, 33-46.

Antioco, M., Moenaert, R. K., Lindgreen, A., \& Wetzels, M. G. M. (2008). Organizational antecedents to and consequences of service business orientations in manufacturing companies. Journal of the Academy of Marketing Science, 36(3), 337-358.

Araujo, L., Dubois, A. \& Gadde, L. (2003). The Multiple Boundaries of the Firm. Journal of Management Studies, 40(5), 1255-1277.

Auguste, B., Harmon, E. \& Pandit, V. (2006). The right service strategies for product companies. The McKinsey Quarterly, 1, 40-51.

Baines, T.S. \& Lightfoot, H.W. (2014). Servitization of the manufacturing firm. Exploring the operations practices and technologies that deliver advanced services. International Journal of Operations \& Production Management, 34(1), 2-35.

Baines T.S. \& Lightfoot, H. (2013). Made to serve. How manufacturers can compete through servitization and product-service systems', Chichester, UK: Wiley.

Baines, T.S, Lightfoot, H.W, Benedettini, O., \& Kay, J.M. (2009). The servitization of manufacturing: A review of literature and reflection on future challenges. Journal of Manufacturing Technology Management, 20(5), 547-567.

Baines, T., Lightfoot, H., \& Smart, P. (2011). Servitization within manufacturing: Exploring the provision of advanced services and their impact on vertical integration. Journal of Manufacturing Technology Management, 22(7), 947-954.

Barnett, N., Parry, G., Saad, M., Newnes, L., \& Goh, Y.M. (2013). Servitization: is a paradigm shift in the business model and service enterprise required? Strategic Change, Special issue on New Entrepreneurial Models, 22(3-4), 145-156.

Barney, J. (1991). Firm resources and sustained competitive advantage. Journal of Management, 17(1), 99-120.

Barney, J.B., Ketchen, D.J. \& Wright, M. (2011). The future of resource-based theory: Revitalization or decline? Journal of Management, 37(5), 1299-1315.

Bastl, M., Johnson, M., Lightfoot, H. \& Evans, S. (2012). Buyer-supplier relationships in a servitized environment : An examination with Cannon and Perreault's framework. International Journal of Operations \& Production Management 32(6), 650-675.

Benedettini, O., Swink, M., \& Neely, A. (2015). Why do servitized firms fail? A risk-based explanation. International Journal of Operations \& Production Management, 35(6), 946-979.

Bengtsson, M. \& Kock, S. (2014). Coopetition-Quo Vadis? Past accomplishments and future challenges, Industrial Marketing Management, 43, 180-188. 
Final version accepted for Publication

Bharadwaj, S. G., Varadarajan, P. R., \& Fahy, J. (1993). Sustainable Competitive Advantage in Service Industries: A Conceptual Model and Research Propositions. Journal of Marketing, 57(4), 83-99. http://doi.org/10.2307/1252221

Bolton, R.N., Smith, A.K. \& Wagner, J. (2003). Striking the Right Balance. Designing Service to Enhance Business-to-Business Relationships. Journal of Service Research, 5(4): 271-291.

Brax, S. \& Jonsson, K. (2009). Developing integrated solution offerings for remote diagnostics. A comparative case study of two manufacturers. International Journal of Operations and Production Management, 29(5), 539-560.

Bryman, A. (2008). Social Research Methods (3rd ed.). Oxford, UK: Oxford University Press.

Ceci, F. \& Prencipe, A. (2008). Configuring Capabilities for Integrated Solutions: Evidence from the IT Sector. Industry and Innovation, 15(3), 277-296.

Cepeda, G. \& Vera, D, (2007). Dynamic Capabilities and Operational Capabilities: A Knowledge Management Perspective, Journal of Business Research, 60, 426-437.

Cova, B. \& Salle, R. (2008). Marketing solutions in accordance with the SD logic: Co-creating value with customer network actors. Industrial Marketing Management. 37(3), 270-277.

Crabtree, B.F., \& Miller, W.L. (1999). Using codes and code manuals: A template organizing style of interpretation. In B.F. Crabtree \& W.L. Miller (Eds.), Doing qualitative research (2nd ed., pp. 163-178). Newbury Park, CA: Sage.

Creswell, J.W. \& Miller, D.L. (2000). Determining Validity in Qualitative Inquiry. Theory into Practice, 39(3), 124-130.

Czarniawska, B., (2009). Narratives in Social Science Research. London: Sage.

Davies, A. (2004). Moving base into high-value integrated solutions: A value stream approach. Industrial and Corporate Change, 13(5), 727-756.

Davies, A., Brady, T. \& Hobday, M. (2007). Organizing for solutions: System seller vs. systems integrator. Industrial Marketing Management, 36(2), 183-193.

Dachs, B., Biege, S., Borowiecki, M., Lay, G., Jäger, A. \& Schartinger, D. (2014). Servitisation in European manufacturing industries: Empirical evidence from a large-scale database. The Service Industries Journal, 34(1), 5-23.

Daliwal, J.S., Macintyre, M. \& Parry, G. (2011). Understanding services and the customer response. In Macintyre, M., Parry, G. \& Angelis, J. (eds., pp. 1-19), Service Design and Delivery. Springer: New York.

Dexter, L. A. (2012). Elite and Specialized Interviewing. Colchester: ECPR press.

Dubois, A., \& Gadde, L.-E. 2002. Systematic combining: An abductive approach to case research, Journal of Business Research, 55(7), 553-560

Eggert, A., Hogreve, J., Ulaga, W. \& Muenkhoff, E. (2011), Revenue and profit implications of industrial service strategies. Journal of Service Research, 17(1), 23-39. 
Final version accepted for Publication

Eggert, A., Thiesbrummel, C., \& Deutscher, C. (2015). Heading for new shores: Do service and hybrid innovations outperform product innovations in industrial companies?. Industrial Marketing Management, 45, 173-183.

Eisenhardt, K.M. (1989). Building theories from case study research. Academy of Management Review, October, 14(4), 532-550.

Evanschitzky, H., Wangenheim, F. V. \& Woisetschlager, D. M. (2011). Service and Solution Innovation: Overview and Research Agenda. Industrial Marketing Management, 40, 657-660.

Fang, E, Palmatier, R \& Steenkamp, J (2008). Effect of service transition strategies on firm value. Journal of Marketing, 72(4), 1-14.

Ford, D., Gadde, L., Håkansson, H. \& Snehota, I. (2003). Managing Business Relationships, (2nd ed.) (pp. 120-121).Chichester: John Wiley.

Furlan, A., Grandinetti, R. \& Camuffo, A. (2009). Business Relationship Portfolios and Subcontractors' Capabilities. Industrial Marketing Management, 38, 937-945.

Gabriel, Y., \& Griffiths, D. (2004). Stories in organizational research. In C. Cassell \& G. Symon (Eds.), Essential guide to qualitative methods in organizational research (pp. 114-126). London: Sage.

Gebauer, H, Fleisch, E \& Friedli, T (2005). Overcoming the service paradox in manufacturing companies. European Management Journal, 23(1), 14-26.

Gebauer, H., Edvardsson, B., Gustafsson, A. \& Witell, L. (2010). Match or mismatch: strategy configurations in the service business of manufacturing companies. Journal of Service Research, 13(2), 198-215.

Gebauer, H., Paiola, M. \& Saccani, N. (2013). Characterizing service networks for moving from products to solutions. Industrial Marketing Management, 42(1), 31-46.

Goffin, K., Lemke, F. \& Szwejczewski, M. (2006). An Exploratory Study of 'Close' SupplierManufacturer Relationships. Journal of Operations Management, 24, 189-209.

Gremyr, I., Löfberg, N., \& Witell, L. (2010). Service innovations in manufacturing firms. Managing Service Quality, 20(2), 161-175

Grönroos, C. \& Helle, P., (2010). Adopting a Service Logic in manufacturing, Journal of Service Management, 21(5), 564-590

Guajardo, J., Cohen, M., Netessine, S. \& Kim, S. (2011). Impact of performance-based contracting on product reliability: an empirical analysis. Management Science, 58, 61-979.

Håkansson, H. \& Ford, D. (2002). How Should Companies Interact in Business Networks. Journal of Business Research, 55(2), 133-139.

Håkansson, H., Ford, D., Gadde, L-E., Snehota, I. \& Waluszewski, A. (2009). Business in Networks, Chichester, England: John Wiley \& Sons Ltd. 
Final version accepted for Publication

Håkansson, H. \& Snehota, (1998). The Burden Of Relationships Or Who's Next' in Naude, P. \& Turnbull, P.W. Network Dynamics in International Marketing. Oxford Elsevier Science 1998.

Håkansson, H. \& Waluszewski, A. (2013) A never ending story - Interaction patterns and economic development. Industrial Marketing Management, 42, 443-454.

Helander, A. \& Möller, K. (2007). System supplier’s customer strategy. Industrial Marketing Management, 36, 719-730.

Helfat, C.E. \& Lieberman, M. (2002). The birth of capabilities: Market entry and the importance of prehistory. Industrial and Corporate Change, 12, 725-760.

Helfat, C.E. \& Winter, S.G. (2011). Untangling Dynamic and Operational Capabilities: Strategy for the (N)ever-Changing World. Strategic Management Journal, 32(11), November, 1243-1250.

Hirschman, E.C. (1986). Humanistic Inquiry in Marketing Research: Philosophy, Method and Criteria. Journal of Marketing Research, 23, 237-249.

Jacobides, M.G. \& Winter, S.G. (2012). Capabilities: Structure, Agency, and Evolution. Organization Science, 23(5), 1365-1381.

Johanson, J \& Mattsson, L.-G. (1992). Network Positions And Strategic Action - An Analytical Framework; in Industrial Networks, A New View Of Reality. Axelsson, Bjórn \& Geoffrey Easton, (eds.) London, UK: Routledge.

Johnsen, R.E. \& David Ford, D. (2006). Interaction capability development of smaller suppliers in relationships with larger customers. Industrial Marketing Management, 35, 1002-1015.

Johnstone, S., Dainty, A. \& Wilkinson, A. (2009). Integrating products and services through life: an aerospace experience. International Journal of Operations and Production Management, 29(5), 520-538.

Kemper, E., Stringfield, S. \& Teddlie, C. (2003). Mixed methods sampling strategies in social science research. In A. Tashakkori \& C. Teddlie (Eds.), Handbook of Mixed Methods in Social and Behavioural Research (Ch.10). Thousand Oaks, CA: Sage.

Kindström, D. \& Kowalkowski, C. (2014). Service innovation in product-centric firms: A multinational business model perspective. Journal of Business \& Industrial Marketing, 29(2), 96111.

King, N. (1998). Template analysis. In C. Cassell \& G. Symon (Eds.), Qualitative methods and analysis in organizational research (pp. 118-134). London: Sage.

King, N. (2004). Using templates in the thematic analysis of text. In C. Cassell \& G. Symon (Eds.), Essential guide to qualitative methods in organizational research (pp. 256-270). London: Sage.

Kohli, A.K. (2011). Looking through the lens of B2B and beyond...., Industrial Marketing Management, 40(2), February, 193-194. 
Final version accepted for Publication

Kohtamäki, M., Partanen, J., Parida, V. \& Wincent, J. (2013). Non-linear relationship between industrial service offering and sales growth: The moderating role of network capability. Industrial Marketing Management, 42, 1374-1385.

Kothandaraman, P. \& Wilson, D.T. (2001). The Future of Competition. Value-Creating Networks. Industrial Marketing Management, 30, 370-389.

Kowalkowski, C., Kindström, D. \& Witell, L. (2011). Internalisation or externalisation?: Examining organisational arrangements for industrial services. Managing Service Quality, 21(4), 373-391.

Lado, A.A., Paulraj, A. \& Chen, I.J. (2011). Customer focus, supply-chain relational capabilities and Performance Evidence from US manufacturing industries. The International Journal of Logistics Management, 22(2), 202-221.

Lepak, D., Smith, K.G., Taylor, M.S., (2007). Value creation and value capture: A multilevel perspective. Academy of Management Review, 32(1), 180-194.

Lightfoot, H.W., \& Gebauer, H. (2011). Exploring the alignment between service strategy and service innovation. Journal of Service Management, 22(5), 664 - 683.

Loasby, B. (1998). The organization of capabilities. Journal of Economic Behavior and Organization, 35, 139-160.

Madhavaram, S. R. \& Hunt, S. D. (2008). The Service-Dominant Logic and a Hierarchy of Operant Resources: Developing Masterful Operant Resources and Implications for Marketing Strategy. Journal Of The Academy Of Marketing Science, 36(1), 67-82

Martinez, V. Bastl, M., Kingston, J., \& Evans, S. (2010). Challenges in transforming manufacturing organisations into product-service providers. Journal of Manufacturing Technology Management, 21(4), 449-469.

Mathieu, V. (2001). Product services: from a service supporting the product to a service supporting the client. Journal of Business \& Industrial Marketing, 16(1), 39-61.

Miles, M.B., \& Huberman, A.M. (1994). Qualitative data analysis (2nd ed., pp. 10-12). Newbury Park, CA: Sage.

Möller, K. \& Rajala, A. (2007). Rise of strategic nets - New modes of value creation. Industrial Marketing Management, 36, 895-908.

Möller, K., Rajala, A.\& Svahn, S. (2005). Strategic Business Nets - Their Type and Management. Journal of Business Research, 58, 1274-1284

Neely, A. (2008). Exploring the financial consequences of the servitization of manufacturing, Operations Management Research, 1, 103-118.

Neu, W. \& Brown, S. (2005). Forming successful business-to-business services in goods-dominant firms. Journal of Service Research, 8(1), 3-17. 
Final version accepted for Publication

Ng, I., Parry, G. Maull, R. \& McFarlane, D. (2011). Complex engineering service systems: A grand challenge. In Ng, I., Parry, G., Wilde, P., McFarlane, D., \& Tasker, P. (eds., pp. 439-454). Complex engineering service systems: Concepts and Research, Springer: London.

Ngugi, I.K., Johnsen, R.E. \& Erdélyi, P. (2010). Relational capabilities for value co-creation and innovation in SMEs. Journal of Small Business and Enterprise Development, 17(2), 260-278.

Nordin, F. (2008). Linkages between service sourcing decisions and competitive advantage: A review, propositions, and illustrating cases. International Journal of Production Economics, 114, 40-55.

Oliva, R. \& Kallenberg, R. (2003). Managing the transition from products to services. International Journal of Service Industry Management, 14(2), 160-172.

Olsson, R., Gadde, L.-E. \& Hulthén, K. (2013). The changing role of middlemen - Strategic responses to distribution dynamics. Industrial Marketing Management, 42, 1131-1140.

Opresnik, D., \& Taisch, M. (2015). The value of Big Data in servitization. International Journal of Production Economics, 165, 174-184.

Ostrom, A. L., Bitner, M. J., Brown, S. W., Burkhard, K. A., Goul, M., Smith-Daniels, V., Demirkan, H. \& Rabinovich, E., (2010). Moving forward and making a difference: Research priorities for the science of service, Journal of Service Research, 13(1), 4-36.

Paiola, M., Saccani, N., Perona, M., \& Gebauer, H. (2013). Moving from products to solutions: Strategic approaches for developing capabilities. European Management Journal, 31(4), 390409.

Parry, G. \& Tasker, P. (2014). Value and Servitization: Creating Complex Deployed Responsive Services. Strategic Change, 23, 303-315.Penttinen, E. \& Palmer, J. (2007). Improving firm positioning through enhanced offerings and buyer-seller relationships. Industrial Marketing Management, 36, 552-564.

Prahalad, C.K. \& Ramasway, V. (2003). The new frontier of experience innovation. MIT Sloan Management Review, 44(4), 12-18.

Raddats, C. O., \& Burton, J. (2014). Creating multi-vendor solutions: the resources and capabilities required. Journal of Business \& Industrial Marketing, 29 (2), 132-142.

Raddats, C., Burton, J. \& Ashman, R. (2015). Resource configurations for services success in manufacturing companies, Journal of Service Management, 26(1), 97-116.

Raddats, C. \& Easingwood, C. (2010). Services growth options for B2B product-centric businesses, Industrial Marketing Management, 39(8), 1331-1342.

Ritter, T. (1999). The Networking Company. Industrial Marketing Management, 28, 467-479.

Salonen, A. (2011). Service transition strategies of industrial manufacturers. Industrial Marketing Management, 40(5), 684.

Sawhney, M., Balasubramanian, S., \& Krishnan, V.V. (2004). Creating growth with services. Sloan Management Review, 45, 34-43. 
Final version accepted for Publication

Selviaridis, K., Spring, M. \& Araujo, L. (2013). Provider involvement in business service definition: A typology. Industrial Marketing Management, 42, 1398-1410.

Smirnova, M., Naude, P., Henneberg, S.C., Mouzas, S. \& Kouchtch, S.P. 2011. The impact of market orientation on the development of relational capabilities and performance outcomes: The case of Russian industrial firms. Industrial Marketing Management, 40(1), 44-53.

Spring, M. \& Araujo, L. (2013). Beyond the service factory: Service innovation in manufacturing supply networks. Industrial Marketing Management, 42(1), 59-70.

Spring, M. \& Araujo, L. (2014). Indirect capabilities and complex performance. Implications for procurement and operations strategy. International Journal of Operations \& Production Management, 34(2), 150-173.

Storbacka, K. (2011). A solution business model: Capabilities and management practices for integrated solutions. Industrial Marketing Management, 40(5), 699-711.

Teece, D. (2007). Explicating dynamic capabilities: The nature and microfoundations of (sustainable) enterprise performance, Strategic Management Journal, 28(13), 1319-1350.

Theoharakis, V., Sajtos, L. \& Hooley, G. (2009). Marketing alliances, firm networks, and firm value creation. Journal of Marketing, 73(5), 52-69.

Tuli, K., Kohli, A \& Bharadwaj, S. (2007). Rethinking Customer Solutions: From Product Bundles to Relational Processes. Journal of Marketing, 71(March), 1-17.

Ulaga, W. \& Reinartz, W.J. (2011). Hybrid offerings: how manufacturing firms combine goods and services successfully, Journal of Marketing, 75(6), 5-23.

Vandermerwe, S. \& Rada, J. (1988). Servitization of business: Adding value by adding services. European Management Journal, 6, 314-324.

Vargo, S. L. \& Lusch, R. F. (2008). Service-Dominant Logic: Continuing Revolution. Journal of Academy of Marketing Science, 36(1), 1-10

Vargo, S. L. \& Lusch, R. F. (2011). It‘s all B2B and Beyond...: Toward a Systems Perspective of the Market. Industrial Marketing Management, 40 (2), 181-187.

Walter, A., Auer, M. \& Ritter, T. (2006). The impact of network capabilities and entrepreneurial orientation on university spin-off performance. Journal of Business Venturing, 21(4), 541-567.

Welch, C., Marschan-Piekkari, R., Penttinen, H., \& Tahvanainen, M. (2002). Corporate elites as informants in qualitative international business research. International Business Review, 11(5), 611-628.

Wernerfelt, B. (1984). A resource-based view of the firm. Strategic Management Journal, 5(2), 171180.

Wilson, D.T. (2000). Deep relationships: The Case of the Vanishing Salesperson. Journal of Personal Selling \& Sales Management, XX(1), 53-61.

Yin, R.K. (2014). Case study research: Design and methods, London: Sage. 